NBER WORKING PAPER SERIES

\title{
EDUCATION AND LABOR MARKET CONSEQUENCES OF TEENAGE CHILDBEARING: EVIDENCE USING THE TIMING OF PREGNANCY OUTCOMES AND COMMUNITY FIXED EFFECTS
}

\author{
Jason M. Fletcher \\ Barbara L. Wolfe \\ Working Paper 13847 \\ http://www.nber.org/papers/w13847
NATIONAL BUREAU OF ECONOMIC RESEARCH
1050 Massachusetts Avenue
Cambridge, MA 02138
March 2008

\begin{abstract}
We thank participants at the Institute for Research on Poverty Seminar Series at the University of Wisconsin-Madison for helpful comments and Deborah Johnson and Ronice Copeman for excellent editing. Part of this research was conducted while Wolfe was at the Netherlands Institute for Advanced Study. All errors are our own. This research uses data from Add Health, a program project designed by J. Richard Udry, Peter S. Bearman, and Kathleen Mullan Harris, and funded by a grant P01-HD31921 from the National Institute of Child Health and Human Development, with cooperative funding from 17 other agencies. Special acknowledgment is due Ronald R. Rindfuss and Barbara Entwisle for assistance in the original design. Persons interested in obtaining data files from Add Health should contact Add Health, Carolina Population Center, 123 W. Franklin Street, Chapel Hill, NC 27516-2524 (addhealth@ unc.edu). The views expressed herein are those of the author(s) and do not necessarily reflect the views of the National Bureau of Economic Research.
\end{abstract}

NBER working papers are circulated for discussion and comment purposes. They have not been peerreviewed or been subject to the review by the NBER Board of Directors that accompanies official NBER publications.

(C) 2008 by Jason M. Fletcher and Barbara L. Wolfe. All rights reserved. Short sections of text, not to exceed two paragraphs, may be quoted without explicit permission provided that full credit, including (C) notice, is given to the source. 
Education and Labor Market Consequences of Teenage Childbearing: Evidence Using the Timing of Pregnancy Outcomes and Community Fixed Effects

Jason M. Fletcher and Barbara L. Wolfe

NBER Working Paper No. 13847

March 2008

JEL No. J13,J24

\section{ABSTRACT}

The question of whether giving birth as a teenager has negative economic consequences for the mother remains controversial despite substantial research. In this paper, we build upon existing literature, especially the literature that uses the experience of teenagers who had a miscarriage as the appropriate comparison group. We show that miscarriages are not random events, but rather are likely correlated with (unobserved) community-level factors, casting some doubt on previous findings. Including community-level fixed effects in our specifications lead to important changes in our estimates. By making use of information on the timing of miscarriages as well as birth control choices preceding the teenage pregnancies we construct more relevant control groups for teenage mothers. We find evidence that teenage childbearing likely reduces the probability of receiving a high school diploma by 5 to 10 percentage points, reduces annual income as a young adult by $\$ 1,000$ to $\$ 2,400$, and may increase the probability of receiving cash assistance and decrease years of schooling.

Jason M. Fletcher

Yale University

School of Public Health

60 College Street, \#303

New Haven, CT 06510

jason.fletcher@yale.edu

Barbara L. Wolfe

University of Wisconsin

1225 Observatory Dr

Madison, WI 53706

and NBER, and Australian National University

BWolfe@wisc.edu 


\section{$\underline{\text { Introduction }}$}

The issue of the economic consequences of teenage childbearing for young women has been the subject of a great deal of debate. Early estimates suggested large consequences in terms of reduced schooling, increased take-up of cash assistance, and lower earnings (see below). Subsequent studies, however, provide evidence that these consequences, if they exist at all, are small. The "explanation" offered is that the adolescents who give birth as teens would have a life trajectory of limited education and earnings even if they had not given birth as a teen. To correctly answer the question of the consequences of teenage childbearing, one requires an accurate measure of the counterfactual — what would have happened to the young woman had she not given birth as a teen. This is difficult, as we observe each individual in only one situation, either as a person who gave birth as a teen or one who did not. Recent studies employ an instrumental variable approach making use of a group of adolescents who, though pregnant as teens, did not give birth. These studies focus especially on teens who miscarried in an attempt to obtain improved estimates (see for example Hotz, McElroy, Sanders 2005). Still others use propensity score matching in an attempt to create an appropriate comparison group (for example, Lee 2007).

In this paper we make use of a rich data set on a group of young women and estimate both OLS and instrumental variables models employing alternative comparison groups, in an attempt to more accurately measure the counterfactual. Our contribution is to add measures of the social environment of the teen and the use of timing of miscarriages/stillbirths to address the determinants of outcomes of teen pregnancy and to obtain more accurate estimates of the effect of giving birth as a teen on subsequent 
outcomes. We find evidence that having a child as a teenager likely reduces the probability of receiving a high school diploma by 5 to 10 percentage points and reduces income as a young adult by $\$ 1,000$ to $\$ 3,000$ in the year of the survey. We find some suggestive evidence that teenage childbearing increases the probability of receiving cash assistance and slightly decreases years of schooling. Our results also suggest the difficulty of estimating the causal effects of teenage childbearing due to the challenge of constructing a relevant control group as well as the need to control for community-level factors that likely are associated with having a pregnancy, the birth outcome of the pregnancy, and early adult labor market and human capital outcomes.

\section{Background}

The initial or simple approach to estimating the consequences of teenage childbearing on the mother uses a straightforward OLS regression specification with some controls for background information to estimate the impact. Studies that use this approach typically find the consequences of teenage childbearing to be large and significant. For example, Moore and Waite (1977) find that teenage mothers complete 1 to 4 fewer years of school than other women by age 24. A second generation of studies attempts to account for the choice of timing of births and find considerably less tie between giving birth as a teen and subsequent schooling. ${ }^{1}$ A third generation of studies uses an instrumental variable approach to compare outcomes and generally find no negative effect of giving birth as a teen on level of schooling or a counterintuitive positive influence (Hotz et al. 2005) (henceforth HMS). The unique or clever insight of

\footnotetext{
${ }^{1}$ See Ribar 1994 for a review of this literature. A related literature on the determinants of teen births also provides evidence that those who give birth are a self-selected group. See, for example, Wolfe, Haveman, Pence, \& Schwabish 2007.
} 
HMS is to compare those who gave birth as teens to those who miscarry, a group who presumably would have carried to term if able to do so. Those who miscarry thus are used as the counterfactual. ${ }^{2}$

Ashcraft and Lang (2006) (henceforth AL) go a step further than previous thirdgeneration papers in that they recognize that some of those who miscarry would have had an abortion had they not miscarried. As such, they should not serve as appropriate models for the "counterfactual." AL present evidence that many miscarriages are earlier than abortions, which suggests that assuming that individuals who miscarry are a valid counterfactual group for those who give birth is problematic. They then use an instrumental variable approach to narrow the possible range of effects--first assuming all miscarriages occur before abortion decisions and then assuming all abortions occur before miscarriages. Finally, AL use standard OLS and IV specifications but alternate between several comparison groups to further narrow the bounds of the estimates. ${ }^{3}$ They find a small but negative effect of giving birth as a teen on subsequent schooling, especially on obtaining a GED. Their results that assume all abortions occur before miscarriages are similar to those of HMS for years of schooling.

We build on the work of AL and all the others who came before us using miscarriage as an instrument. However, we test for the sensitivity of whether some

\footnotetext{
${ }^{2}$ The small number of teenagers (69 individuals) who report a miscarriage and the accuracy of reports of abortions, miscarriages, and pregnancies in the NLSY data are two critiques of this approach. See Hoffman 2003 for others.

${ }^{3}$ AL's first use all individuals who became pregnant but did not give birth as the comparison group (including miscarriages and abortions). This estimate for childbearing should provide the upper bound on the negative effects of teen childbearing since those who had an abortion self-select out of bearing a child as a teen. AL next present results where only individuals who miscarried serve as the comparison group. Since the miscarriage group comprises individuals who would have carried the birth to term and those who would have received an abortion, the results are still expected to be biased toward finding negative effects of teenage childbearing but less so than the first comparison. Finally, AL estimate IV specifications that are expected to be biased toward finding positive effects. The range of estimates across specifications AL present (OLS for the upper bound on negative effects and IV specifications for the lower bound) should bound the true effect.
} 
teenagers who have a miscarriage would have had an abortion. We do so making use of our data on the timing of the termination of a pregnancy (by abortion or miscarriage). We also add information on the environment in which these pregnancy outcomes occur to this analysis. Specifically, we use several measures of the teenager's environment, including the pregnancy outcomes of other teenagers in her community, measures of community disadvantage, and state laws affecting access to abortion. In order to clarify the influence of giving birth as a teen on her subsequent well-being we include a broad set of human capital outcome measures including three indicators of schooling, earnings, receipt of welfare and income. Finally, we make use of our information on whether the adolescent was practicing birth control at the time of the fertilization as a measure of whether or not she actively sought to prevent the pregnancy.

\section{Data}

The data we use in our analysis are from the restricted version of the National Longitudinal Study of Adolescent Health (Add Health). We use only young women who were pregnant as an adolescent in our analysis. There are 4,943 pregnancies reported by women in our sample by Wave III of data collection (when the respondents were on average 22 years old). We limit our analysis sample by focusing on first pregnancies (leaving 3,633 pregnancies) and on pregnancies that ended before age 18 years and 9 months (leaving 1,089 observations). We then exclude 18 women who report still being in high school, 15 women who gave birth to only one twin and 2 women whose pregnancy had not ended at the time of the interview, leaving 1,054 observations. We combine reported miscarriages and still-births into one category_-"miscarriages." 
Omitting those with missing community-level data leave us a sample of approximately 1,000 though this varies slightly by outcome. We impute data for parental education and family income for nearly 300 individuals and include a dummy variable for individuals with missing data. For community-level variables, we include state-level information on abortion laws and funding levels (merged from data reported in the 1995 version of the National Abortion Rights Action League (NARAL) publication "Who Decides? A Stateby-State Review of Abortion Rights.") and Census information on the proportion of individuals in poverty as well as other measures, including the education level of census tract 'neighbors', that was merged from the Summary Tape File of the 1990 Census of Population and Housing. In addition, we construct measures of the proportion of all pregnancies in the each community that are resolved as live births, miscarriages, and abortions (excluding the individual from the calculation). These proportions attempt to measure unobserved community-level factors that increase the likelihood of each pregnancy outcome.

The adolescents who serve as our controls or counterfactuals are those who report a miscarriage while a teen. Our primary analysis focuses on this group. However, a number of these adolescents might have chosen to have an abortion had they not had a miscarriage. Hence, we also conduct an analysis in which only those who had a "late" miscarriage serve as the control group. This reduces the possible bias on comparing those who gave birth to those who would have terminated their pregnancy in the absence of a miscarriage. As noted by AL and confirmed in our own analysis, teens who terminate their pregnancy through an abortion tend to come from higher SES families. Hence, including them as controls in the miscarriage group would likely bias the results 
on the consequences of giving birth as a teen toward an underestimate of the "true" effect. By using both of these two comparison or control groups, we believe we narrow the range of estimates of the effect of giving birth while a teen on SES outcomes as young adults.

Table 1 provides basic summary statistics for our sample. Conforming with other national data sets, pregnancies end in live births, abortions, and miscarriages (or stillbirths) for $59 \%, 25 \%$, and $16 \%$ of our sample, respectively. Since potential biases in self-reports of pregnancy outcomes have been raised in previous work (for example, Hotz et al. 2005), two differences in the Add Health data are worth noting. First, respondents in the Add Health survey used computer-assisted personal interview (CAPI) technology, where sensitive questions were answered using a laptop rather than verbally indicated to the interviewer. This feature of the survey design is in contrast with other surveys for which biases in self-reported pregnancy outcomes have been shown (for example, the National Survey of Family Growth, National Longitudinal Study of Youth). Second, the self-reported pregnancy outcomes in Add Health match more closely with official Vital Statistics than other datasets. For example, $25 \%$ of first pregnancies are reported to end in abortion and $16 \%$ end in miscarriage, compared with (only) $18 \%$ and $7 \%$, respectively, in Hotz et al. (2005).

Of the women in our sample (who have all experienced a teen pregnancy), $68 \%$ receive a high school diploma and 13\% receive a GED. Thirteen percent receive cash assistance as a young adult and $40 \%$ report using birth control before their pregnancy.

Table 2 stratifies the summary statistics by each of the pregnancy outcomes and also by the timing of miscarriages into "early" and "late," which is categorized based on 
eight weeks, the modal timing of a miscarriage in our data (full summary statistics can be found in appendix tables $1 \mathrm{~A}-5 \mathrm{~A})$. The raw means suggest that even conditional on this sample of women who experienced a teen pregnancy; those who elected to have an abortion were more advantaged than those who had a miscarriage or live birth. Women who had an abortion scored higher on an achievement test (Peabody Picture Vocabulary Test), were from families with higher incomes, had more educated parents, and lived in communities with lower poverty rates than women who miscarried or had a live birth.

When we divide the sample of miscarriages between early and late miscarriages, there is evidence that some individuals who had an early miscarriage may have had an abortion rather than a live birth. While these two groups have very similar demographics, the individuals who experienced an early miscarriage were more likely to have used birth control prior to getting pregnant. On the other hand, individuals who experienced a late miscarriage are slightly more advantaged, as measured by several family background variables.

\section{Methodology}

Our interest is in identifying the true effect of giving birth as a teen on outcomes as a young adult. That is, we wish to estimate

$$
\mathrm{Y}=\alpha+\beta \mathrm{B}+\mu
$$

where $\mathrm{Y}$ is the outcome of interest such as years of schooling or earnings as a young adult, $\mathrm{B}$ is an indicator of giving birth as a teen, and $\beta$ is the coefficient of interest. The "core problem" is that those who give birth may differ in systematic ways from those 
who do not and these systematic differences are also likely to determine the outcome. The $\beta$ estimated this way would overestimate the true influence of giving birth on Y.

The simplest way to handle this is to add other control variables to the equation. These might include background factors such as the SES of the family in which the teen was raised, race/ethnicity, and perhaps some community variables. Equation 1 then becomes:

$$
\mathrm{Y}=\alpha+\beta \mathrm{B}+\theta \mathrm{X}+\mu
$$

where $\mathrm{X}$ is the vector of additional control variables.

However, this still leaves unobserved factors that may influence those who become pregnant, those who choose to give birth, and the outcome. That is, this estimation strategy may still not accurately allow the researcher to identify $\beta$.

Our approach is to limit the sample only to those who became pregnant as a teen, thus identifying the influence of the birth only over those who are "similar" in that they shared the experience of being pregnant by age 18. This eliminates a good deal of the unobserved differences between treatment and control groups. Furthermore, we limit the comparison to those who "chose" not to voluntarily terminate the pregnancy, that is, we compare those who gave birth to those who had a miscarriage. Since some of those who had a miscarriage might have chosen to have an abortion and thus would systematically differ from those who gave birth, we make two alternative assumptions and thus provide a narrow range for our estimate of $\beta$ : (1) all those who had a miscarriage or stillbirth would not have chosen an abortion and (2) all those who had a late miscarriage would not have chosen to have an abortion. In the latter case, we avoid making an assumption of those who had a miscarriage early by omitting them from the comparison group. 
Finally we make use of the school-based design of our dataset by adding community fixed effects to the analyses. This is based on from 60 to 75 communities with an average of 5 to 10 observations per community. We first provide evidence that community-level factors are associated with the probability of having a miscarriage. Thus, previous results found in the literature that use miscarriage as an instrument are likely biased. We then show that controlling for community fixed effects changes the results in both the OLS and IV specifications of outcomes of teen childbearing in important ways.

\section{Estimation Results}

\section{Determinants of Pregnancy Outcomes}

Since previous researchers have argued that miscarriages can be considered (conditionally) random, we examine this assumption using our data. In Table 3, we first estimate the determinants of the outcome of each teen pregnancy using the full sample of teens who were pregnant employing multinomial logistic regression. The three possible outcomes are give birth, abortion, or miscarriage (omitted category). The results indicate that the choice of abortion is not random but indeed is made by those from more advantaged backgrounds. For example, those who have an abortion tend to have higher Peabody Picture Vocabulary test scores, reside in communities with lower poverty levels, and have parents with more education compared to those who give birth, findings that are consistent with those of An, Haveman, and Wolfe (1993). If they live in a state with public funding for abortions, they are also more likely to have an abortion. Consistent with the literature (see, for example, Coleman 2006), blacks are less likely to have a 
miscarriage (though this estimate is not statistically significant) than are adolescents who are white or Hispanic. Like AL, we find evidence that smoking during pregnancy increases the risk of miscarriage in our data, and find that drinking and drug use also appear to predict birth outcomes. Comparing the probability of miscarriages to live births, we find that the proportion of miscarriages in the community is negatively associated with an individual's probability of giving birth or of having an abortion. These results suggest that there could be unmeasured community-level factors that influence the probability of miscarriage, so that the assumption that miscarriages are conditionally random is likely not valid without controlling for community-level factors. In our analysis of the effects of teenage childbearing on life outcomes, we present results that use community-level fixed effects.

\section{The Effects of Teenage Childbearing on Adult Outcomes}

We now estimate the effects of teenage childbearing on education and labor market outcomes using several alternative specifications and samples. In Table 4, we present results using OLS and 2SLS techniques. As noted in AL, controlling for characteristics (for example, race, parental education) that are correlated with both the outcomes of interest as well as birth outcomes could easily worsen or change the sign of the bias in our estimating equations; therefore we follow $\mathrm{AL}$ and only control for factors that have been cited in the medical or economics literature as being risk factors for miscarriage, including whether the pregnancy occurred before age 15 and whether the 
teenager smoke, drank alcohol, or used drugs during the pregnancy (for example , GarciaEnguidanos et al. 2002; Ashcraft and Lang 2006; Hotz et al. 2005). ${ }^{4}$

First, in columns 1 and 2, we follow the "second-generation" papers outlined above and compare the outcomes of young women who gave birth with young women who did not give birth (but had teenage pregnancies). Column 2 adds community-level fixed effects to the specifications of column 1. Comparing across these two columns, community-level fixed effects estimates show a decrease in the estimated effects of teenage childbearing by 10 to $20 \%$ (with the exceptions of GED and total income). Column 2 shows that teenage childbearing is negatively associated with receipt of a high school diploma (16 percentage points), years of education ( 0.8 years), household income $(\$ 2,700)$, and labor income $(\$ 2,500)$ at Wave 3. Teenage childbearing appears to increase the likelihood of welfare receipt by 8.5 percentage points and has no discernable relationship with GED receipt. However, as other researchers have suggested, specifications like those in columns 1 and 2 are biased toward finding negative effects of teenage childbearing because we are comparing disadvantaged mothers with more advantaged women, although here only with those who were also pregnant as teenagers and lived in the same communities. Finally, in column 2 below the coefficient, standard errors and number of observations we present $p$-values from F-tests of the joint hypothesis that the coefficients on our community fixed effects are equal to zero and a Hausman test that compares our coefficients across specifications with and without

\footnotetext{
${ }^{4}$ Tobacco (in particular, nicotine) is thought to produce vascular spasms, resulting in placental pathology (Brent \& Beckmann 1994). For alcohol, while there is some mixed evidence relating moderate alcohol consumption to miscarriage, Abel (1997) showed that high blood alcohol levels could directly provoke miscarriage. Finally, while marijuana use has not been conclusively tied to miscarriage, cocaine use and heroin use are less controversial determinants of miscarriage (for example, Chasnoff, Burns, Schnoll, \& Burns 1985).
} 
community fixed effects. For all three education outcomes and welfare receipt our community level fixed effects are jointly statistically significant at the $5 \%$ level; for wages at the $7 \%$ level. Our Hausman tests show evidence of statistically different coefficient estimates for high school diploma and years of schooling, but in other cases, the coefficients are similar. Since these results suggest strong but not overwhelming support for the value of our community fixed effects strategy we present our estimates including and excluding community fixed effects in our following tables.

Columns 3 and 4 in Table 4 show results for two-stage least square specifications, where we follow HMS and AL and use miscarriage as an instrument for live births. AL shows that these specifications should be biased toward finding beneficial effects of teenage childbearing. Indeed, our results suggest that there is no statistically significant relationship between teenage childbearing and any of the education and labor outcomes we examine. Importantly, though, several results suggest that our bounds of the true effect (where columns 1 and 2 provide the upper bound and columns 3 and 4 provide the lower bound) are relatively tight.

Columns 5 and 6 show results that use OLS to estimate the relationship between teenage childbearing and our set of outcomes, but constrain the control group to comprise only individuals who experienced a miscarriage (rather than combining miscarriage and abortion). This is one of our preferred specifications. As expected, the magnitudes of the coefficients change considerably (most by more than $20 \%$ ) when constraining the control group to miscarriages (column 1 versus column 5). Further, the results in column 6 suggest that including community fixed effects also considerably changes the basic results. In particular, we estimate much lower effects of teen childbearing on welfare 
receipt (11 versus 3 percentage points) and years of schooling ( 0.5 years versus 0.12 years) after adjusting the birth/miscarriage estimates for community fixed effects. In contrast, the relationships between teenage childbearing and wages, income, and high school completion are relatively stable after controlling for community fixed effects, suggesting a small decrease in the probability of high school completion (-0.09) and lower income and earnings of $\$ 2,700$ and $\$ 2,400$ annually, respectively (the latter are not statistically significant at standard levels). Finally, in columns 7 and 8, we use "late" miscarriages as our comparison group, which we define as a miscarriage after 8 weeksthe modal length of pregnancies ending in miscarriage in our data. We perform this analysis in a further attempt to compare pregnant women who would have given birth (had they not experienced a miscarriage) with women who completed their pregnancies. As noted above, using all women who miscarry as the comparison may include some women who would have had an abortion had they not experienced an 'early' miscarriage. Once again the results for the relationship between teen childbearing and wages and income are quite consistent with the earlier ones and suggest a substantial reduction in both tied to teen childbearing. In this case, the estimates controlling for community characteristics (FE) exceed those that do not and suggest a reduction of $\$ 2,800$ in wages and nearly $\$ 3,000$ in family income. None of the other results are statistically significant although the point estimates suggest a very modest reduction in the probability of obtaining a high school degree.

\section{Robustness Checks}


To further examine the robustness of our results, we examine specifications that stratify our results based on birth control choices predating the pregnancy. In Table 5, we re-estimate our previous table using first the entire miscarriage group (columns 1 and 2) and then those with only a late miscarriage (columns 3 and 4 ) as our control group.

Here our focus is on whether those who used birth control, and thus would appear to wish to prevent a pregnancy, are different in terms of future consequences. ${ }^{5}$ Thus we stratify our results by use of birth control prior to pregnancy to compare results for women who were actively attempting to prevent pregnancy and those who were not (see Table 6 and Table $6 \mathrm{~A}$ for full results and a comparison based on birth control use). ${ }^{6}$ Like Table 4, our results seem to be most robust for the outcomes of income and wages for those who used birth control but are much weaker for those who did not. Thus these results suggest a larger negative influence on wages and family income for those teens who had been using birth control prior to becoming pregnant compared to all teens that gave birth. This is the case even though the number of observations is considerably smaller than for the entire group of teens. Furthermore the estimated influence is somewhat reduced when we use community controls via FE but still suggest a reduction in excess of $\$ 3,000$ for total income and nearly $\$ 3,500$ for wages. We find small and imprecisely measured effects on years of schooling and negligible effects on welfare receipt. This estimation then suggests that those who use birth control have an idea that they will face substantial negative consequences should they become pregnant and carry

\footnotetext{
${ }^{5}$ Teenage girls who use birth control might be thought of as having a joint preference for being sexually active but wishing to avoid becoming pregnant. This fits with the idea of rational choice. For other evidence on rational choice of teens, see, for example, Wolfe, Haveman, Pence, \& Schwabish (2007) and Haveman, Wolfe, \& Wilson (2001).

${ }^{6}$ While we report these results using whether or not the individual reports using birth control, we do not emphasize them as some of the samples are quite small. We are also hesitant as those who do not use birth control may be quite heterogeneous including teens who wished to become pregnant with those who did not plan to be sexually active.
} 
the pregnancy to term. These consequences appear most significant for wages and income.

We also ran a similar set of regressions on those teens who gave birth as a teen and did not marry within a year of giving birth. In this we exclude those who married and thus might be expected to have more positive outcomes or to have been more likely to adjust to the birth of the child. For these results we include 848 of the 936 who are in the larger set. These results (shown in appendix Table 7A) suggest a similar pattern to those of the overall group, although the coefficients are somewhat smaller than for the larger group of women. For example, the coefficient using FE is $-2,282$ for total income and $-1,740$ for wages for those who did not marry within a year compared to $-2,710$ and 2,375 , respectively, for the larger sample. We also ran results that control only for age and whether the pregnancy began before age 15 so that several endogenous health behaviors (smoking, drinking, and drug use during pregnancy) are excluded. We found that the main results do not substantially differ with our preferred set of results in Table 7. (See appendix Table 8A for full results).

Finally, we attempted to explore the community determinants of our labor and education outcomes that might underlie the important differences we find when using our FE approach. Here we include variables such as the poverty rate, crime rates, education level of the community, community income, ratio of young adult females to males in the community, and other variables shown in our tables. Results are presented in Table 9A in the appendix. While as a set these community variables are generally statistically significant (the exception is for welfare receipt) they do little to truly explain what it is about a particular community that seems to influence the education, labor force, and 
income outcomes of teen mothers. Our community fixed effects results generally show that there are important community factors at work in influencing such outcomes and that excluding them from the analysis may well lead to biased results. Unfortunately, we have not been able to identify what it is about these communities that seems to matter.

\section{Conclusion}

In this paper, we build on previous research to examine the short-term human capital and labor force consequences of teenage childbearing. We advance the literature in several ways. First, we show that previous 2SLS estimates using miscarriages as the instrument are likely biased. In particular, we present evidence that unobserved community-level characteristics are correlated with the probability of experiencing a miscarriage, which suggests the importance of including community fixed effects when estimating the consequences of teenage childbearing. In fact, we show that controlling for community fixed effects in several cases substantially changes our estimates. Second, we use the information on the timing of miscarriage as well as reports of birth control use prior to pregnancy to create relevant control groups for the women who have children while teenagers. Our most reliable estimates (see column 6 in Tables 4 and 5) provide some evidence that giving birth as a teen is associated with a decline in the probability of graduating from high school (-0.08) and a reduction in income and total wages of $\$ 2,200$ to $\$ 2,400$.

Our results indicate the difficulty of estimating the causal effects of teenage childbearing in many datasets that do not allow the use of community fixed effects and/or have sufficient information from which to construct the relevant control groups. Using 
our rich dataset, we are able to provide relatively tight estimates of bounds of the causal effect of teenage childbearing on human capital and labor force outcomes. We find consistent evidence that teenage childbearing likely lowers the probability of receiving a high school diploma by a small amount but more significantly decreases household income and labor income of women in their early twenties. Our final table, Table 7, brings together our results. In Table 7, we provide a clear comparison of secondgeneration estimates, third-generation estimates, and our preferred estimates that use community fixed effects as well as information on the timing of miscarriage. We show that in many cases, our preferred specifications substantially narrow the bounds on the estimates of the effects of teenage childbearing. For example, in the case of receiving a high school diploma, second-generation methods produce an estimate of -0.18 ( a lower bound) compared with third-generation methods of 0.048 , which have been shown to be an upper bound estimate (AL). In contrast, our preferred lower-bound estimate that assumes that all miscarriages would have not have been abortions produces an estimate of -0.09 , and our preferred upper-bound estimate that assumes that only late miscarriages would have not been abortions produces an estimate of -0.08 - a very tight bound. Our results for years of completed education and welfare receipt show similar tightening of the bounds of the estimated effect of teenage childbearing, while our results for total income and labor income are quite similar to results produced from second- and thirdgeneration methods. In the case of wages, our preferred results have a narrow range of $\$ 2,700$ to $-\$ 2,950$, which are actually greater than those of the birth / no birth comparison shown in column 1. In the case of total income, our preferred results suggest a reduction 
of approximately $\$ 2,400$ to $\$ 2,800$, which are somewhat below the first column estimate of $\$ 3,500$.

Overall, our results using this uniquely rich data set on teens and their communities suggest large reductions in wages and income and a modest reduction in the probability of graduating high school. Perhaps surprisingly, our results suggest no real influence of teen childbearing on years of schooling, welfare receipt, or obtaining a GED. Our results, which use community-level fixed effects and a comparison either to all those who had a miscarriage or only to those who suffered a late miscarriage, provide a relatively narrow range of predictions of the influence of teen childbearing on outcomes as a young adult. They also highlight the importance of comparing those who gave birth to those who are otherwise similar and of including community or neighborhood factors in order to more accurately estimate the young-adult consequences of teen childbearing. 
Table 1

Summary Statistics: National Longitudinal Study of Adolescent Health (Add Health)

Sample of Females who were pregnant by age 18

\begin{tabular}{|c|c|c|c|c|c|}
\hline Variable & Obs & Mean & Std Dev & Min & Max \\
\hline \multicolumn{6}{|l|}{ Birth Outcomes } \\
\hline$\overline{\text { Live Birth }}$ & 1041 & 0.59 & 0.49 & 0 & 1 \\
\hline Miscarriage & 1041 & 0.16 & 0.36 & 0 & 1 \\
\hline Abortion & 1041 & 0.25 & 0.43 & 0 & 1 \\
\hline \multicolumn{6}{|l|}{ Outcomes } \\
\hline$\overline{\text { High School Diploma }}$ & 1038 & 0.68 & 0.47 & 0 & 1 \\
\hline GED & 1039 & 0.13 & 0.34 & 0 & 1 \\
\hline Years of Schooling & 1041 & 12.26 & 1.87 & 7 & 20 \\
\hline Welfare Receipt & 1040 & 0.13 & 0.34 & 0 & 1 \\
\hline Total Income & 987 & 11910 & 13192 & 0 & 200000 \\
\hline Total Labor Income & 1006 & 9304 & 11440 & 0 & 175000 \\
\hline \multicolumn{6}{|l|}{ Individual Characteristics } \\
\hline$\overline{\text { Age }}$ & 1041 & 21.70 & 1.65 & 18 & 27 \\
\hline White & 1041 & 0.43 & 0.50 & 0 & 1 \\
\hline Black & 1041 & 0.34 & 0.48 & 0 & 1 \\
\hline Hispanic & 1041 & 0.18 & 0.38 & 0 & 1 \\
\hline PPVT Test Score & 1041 & 96.03 & 12.69 & 54 & 132 \\
\hline General Health & 1041 & 2.39 & 0.94 & 1 & 5 \\
\hline \multicolumn{6}{|l|}{ Family Characteristics } \\
\hline$\overline{P a r e n t ~ E d u c a t i o n ~}$ & 1041 & 12.74 & 2.14 & 0 & 17 \\
\hline Family Income & 1041 & 35.85 & 26.98 & 0 & 426 \\
\hline Parent Married & 1041 & 0.50 & 0.50 & 0 & 1 \\
\hline Parent Religiosity & 1041 & 23.67 & 18.17 & 0 & 50 \\
\hline Mother Work & 1041 & 0.68 & 0.42 & 0 & 1 \\
\hline Parent Missing Data & 1041 & 0.38 & 0.49 & 0 & 1 \\
\hline \multicolumn{6}{|l|}{ Pregnancy Variables } \\
\hline Used Birth Control & 1017 & 0.40 & 0.49 & 0 & 1 \\
\hline Age Pregnancy Ended & 1041 & 17.28 & 1.10 & 13 & 19 \\
\hline Conception Before Age 15 & 1041 & 0.08 & 0.27 & 0 & 1 \\
\hline Smoke During Pregnancy & 1025 & 0.20 & 0.40 & 0 & 1 \\
\hline Drink During Pregnancy & 1022 & 0.09 & 0.28 & 0 & 1 \\
\hline Drugs During Pregnancy & 1023 & 0.07 & 0.26 & 0 & 1 \\
\hline Weeks Pregnant & 999 & 24.04 & 15.12 & 0 & 40 \\
\hline \multicolumn{6}{|l|}{ Community Variables } \\
\hline$\overline{\text { Median Income (Comm) }}$ & 1041 & 29.24 & 7.62 & 14 & 49 \\
\hline \% Poverty (Comm) & 1041 & 15.02 & 7.51 & 4 & 39 \\
\hline Unemployment Rate (State) & 1041 & 0.07 & 0.02 & 0.03 & 0.15 \\
\hline \% Black (Comm & 1041 & 0.17 & 0.16 & 0 & 1 \\
\hline Rural (Comm) & 1032 & 0.26 & 0.44 & 0 & 1 \\
\hline Urban (Comm) & 1032 & 0.40 & 0.49 & 0 & 1 \\
\hline Violent Crime Per 100K (1000s) (Comm) & 1027 & 0.91 & 0.69 & 0 & 3 \\
\hline Total Crime Per 100k (1000s) (Comm) & 1027 & 6.12 & 2.78 & 0 & 17 \\
\hline Monthly AFDC Per Recipient (State) & 1041 & 115.26 & 50.75 & 42 & 214 \\
\hline Medicaid Proportion Receiving AFDC (State) & 1041 & 0.40 & 0.08 & 0.2 & 0.6 \\
\hline$\%$ College Graduates (Age>25) (Community) & 1041 & 0.25 & 0.07 & 0.1 & 0.4 \\
\hline Sex Ratio (Ages 17-21) (Community) & 1041 & 0.96 & 0.13 & 0.6 & 1.2 \\
\hline
\end{tabular}




\begin{tabular}{|c|c|c|c|c|c|}
\hline Parental Consent Law (State) & 1041 & 0.56 & 0.50 & 0 & 1 \\
\hline Abortion Funding (State) & 1041 & 0.34 & 0.48 & 0 & 1 \\
\hline Proportion Miscarried (Comm Sample) & 1041 & 15.55 & 17.37 & 0 & 100 \\
\hline Proportion Abortion (Comm Sample) & 1041 & 25.23 & 21.08 & 0 & 100 \\
\hline
\end{tabular}

Imputed

Notes: "Parent" refers to the parent of the teenage respondent for the family background variables. Miscarriages include stillbirths. \% miscarriage and abortion are measured within sample for those individuals located in the same community in Wave 1. 
Table 2

Summary Statistics: National Longitudinal Study of Adolescent Health By Pregnancy Outcome

\begin{tabular}{|c|c|c|c|c|c|}
\hline Variable & Live Births & Abortions & Miscarriages & $\begin{array}{c}\text { Late } \\
\text { Miscarriages } \\
\end{array}$ & $\begin{array}{c}\text { Early } \\
\text { Miscarriages } \\
\end{array}$ \\
\hline \multicolumn{6}{|l|}{ Outcomes } \\
\hline High School Diploma & 0.61 & 0.82 & 0.68 & 0.67 & 0.76 \\
\hline GED & 0.14 & 0.11 & 0.14 & 0.16 & 0.07 \\
\hline Years of Schooling & 11.89 & 13.22 & 12.07 & 11.92 & 12.51 \\
\hline Welfare Receipt & 0.17 & 0.06 & 0.12 & 0.14 & 0.07 \\
\hline Total Income & 10911 & 13123 & 13642 & 13187 & 13375 \\
\hline Total Labor Income & 8331 & 10907 & 10398 & 10575 & 10474 \\
\hline \multicolumn{6}{|l|}{ Individual Characteristics } \\
\hline Age & 21.79 & 21.63 & 21.45 & 21.54 & 21.24 \\
\hline White & 0.42 & 0.43 & 0.47 & 0.46 & 0.46 \\
\hline Black & 0.37 & 0.33 & 0.27 & 0.25 & 0.31 \\
\hline Hispanic & 0.18 & 0.15 & 0.23 & 0.24 & 0.22 \\
\hline PPVT Test Score & 94.54 & 100.06 & 95.18 & 95.56 & 95.14 \\
\hline General Health & 2.41 & 2.33 & 2.40 & 2.48 & 2.14 \\
\hline \multicolumn{6}{|l|}{ Family Characteristics } \\
\hline$\overline{\text { Parent Education }}$ & 12.43 & 13.43 & 12.79 & 12.84 & 12.73 \\
\hline Family Income & 32.36 & 44.25 & 35.54 & 36.29 & 34.59 \\
\hline Parent Married & 0.46 & 0.56 & 0.58 & 0.61 & 0.56 \\
\hline Parent Religiosity & 23.19 & 23.06 & 26.45 & 29.05 & 22.06 \\
\hline Mother Work & 0.66 & 0.78 & 0.63 & 0.62 & 0.64 \\
\hline Parent Missing Data & 0.43 & 0.29 & 0.36 & 0.40 & 0.27 \\
\hline \multicolumn{6}{|l|}{ Pregnancy Variables } \\
\hline Used Birth Control & 0.39 & 0.42 & 0.36 & 0.33 & 0.42 \\
\hline Age Pregnancy Ended & 17.33 & 17.17 & 17.26 & 17.28 & 17.20 \\
\hline Conception Before Age 15 & 0.07 & 0.11 & 0.07 & 0.06 & 0.10 \\
\hline Smoke During Pregnancy & 0.15 & 0.26 & 0.28 & 0.33 & 0.20 \\
\hline Drink During Pregnancy & 0.03 & 0.21 & 0.10 & 0.12 & 0.07 \\
\hline Drugs During Pregnancy & 0.03 & 0.16 & 0.10 & 0.11 & 0.08 \\
\hline Weeks Pregnant & 33.20 & 9.81 & 12.78 & 18.66 & 3.80 \\
\hline \multicolumn{6}{|l|}{ Community Variables } \\
\hline Median Income $(\$ 10,000 \mathrm{~s})$ (Comm) & 28.16 & 31.81 & 29.23 & 29.51 & 29.18 \\
\hline$\%$ Poverty (Comm) & 15.81 & 13.30 & 14.85 & 15.06 & 14.20 \\
\hline Unemployment Rate (State) & 0.07 & 0.07 & 0.07 & 0.07 & 0.07 \\
\hline$\%$ Black (Comm) & 0.18 & 0.15 & 0.16 & 0.15 & 0.17 \\
\hline Rural (Comm) & 0.27 & 0.17 & 0.35 & 0.34 & 0.37 \\
\hline Urban (Comm) & 0.41 & 0.37 & 0.38 & 0.39 & 0.32 \\
\hline Violent Crime Per 100K (1000s) (Comm) & 0.90 & 0.95 & 0.91 & 0.93 & 0.83 \\
\hline Total Crime Per 100k (1000s) (Comm) & 6.08 & 6.21 & 6.13 & 5.87 & 6.51 \\
\hline Monthly AFDC Per Recipient (State) & 108.28 & 129.22 & 119.17 & 126.54 & 107.22 \\
\hline Medicaid \% Receiving AFDC (State) & 0.40 & 0.40 & 0.40 & 0.39 & 0.40 \\
\hline$\%$ College Grad (Age>25) (Community) & 0.24 & 0.27 & 0.26 & 0.25 & 0.27 \\
\hline Sex Ratio (Ages 17-21) (Community) & 0.97 & 0.96 & 0.96 & 0.97 & 0.95 \\
\hline Parental Consent Law (State) & 0.63 & 0.46 & 0.46 & 0.41 & 0.51 \\
\hline Abortion Funding (State) & 0.28 & 0.48 & 0.37 & 0.45 & 0.24 \\
\hline Proportion Miscarried (Comm Sample) & 13.71 & 15.47 & 22.65 & 22.86 & 23.16 \\
\hline
\end{tabular}


Imputed

Notes: "Parent" refers to the parent of the teenage respondent for the family background variables. Early miscarriages are those that occurred prior to 8 weeks (the modal week of miscarriage in our data). Miscarriages include stillbirths. \% miscarriage and abortion are measured within sample for those individuals located in the same community in Wave 1. 
Table 3

Determinants of Pregnancy Outcomes

Multinomial Logistic Regression Analysis (Omitted Outcome $=$ Miscarriage $)$

\begin{tabular}{|c|c|c|c|c|}
\hline \multirow[t]{2}{*}{ Outcome } & \multicolumn{2}{|c|}{ Abortion } & \multicolumn{2}{|c|}{ Live Birth } \\
\hline & Coefficient & Std. Error & Coefficient & Std. Error \\
\hline$\%$ Miscarriage in Community & $-0.015^{\star \star \star}$ & $(0.006)$ & $-0.024^{\star \star \star}$ & $(0.006)$ \\
\hline$\%$ Abortion in Community & 0.003 & $(0.006)$ & -0.007 & $(0.005)$ \\
\hline Age $=20$ & $-0.878^{\star}$ & $(0.491)$ & -0.568 & $(0.468)$ \\
\hline Age $=21$ & $-0.934^{\star \star}$ & $(0.458)$ & -0.594 & $(0.408)$ \\
\hline Age $=22$ & $-0.784^{\star}$ & $(0.472)$ & -0.216 & $(0.429)$ \\
\hline Age $=23$ & -0.662 & $(0.497)$ & -0.150 & $(0.443)$ \\
\hline Age $=24$ & -0.014 & $(0.518)$ & 0.401 & $(0.450)$ \\
\hline Age $=25$ & 0.733 & $(0.767)$ & 0.109 & $(0.805)$ \\
\hline Parent Education & 0.020 & $(0.059)$ & $-0.095^{\star}$ & $(0.055)$ \\
\hline General Health & -0.060 & $(0.130)$ & 0.013 & $(0.104)$ \\
\hline Black & 0.439 & $(0.286)$ & 0.236 & $(0.232)$ \\
\hline Hispanic & -0.382 & $(0.316)$ & -0.123 & $(0.257)$ \\
\hline PVT Score & $0.028 * \star \star$ & $(0.010)$ & 0.007 & $(0.010)$ \\
\hline Family Income & 0.010 & $(0.006)$ & -0.001 & $(0.006)$ \\
\hline Parent Age & -0.021 & $(0.018)$ & -0.017 & $(0.015)$ \\
\hline Married Family & -0.324 & $(0.259)$ & -0.322 & $(0.209)$ \\
\hline Missing Parent Data & -0.233 & $(0.225)$ & 0.173 & $(0.201)$ \\
\hline$\%$ Poverty & $-0.033^{*}$ & $(0.019)$ & -0.023 & $(0.017)$ \\
\hline Parent Consent Law (State) & 0.270 & $(0.272)$ & $0.520^{\star *}$ & $(0.224)$ \\
\hline Public Funding for Abortion (State) & $0.654^{\star \star}$ & $(0.254)$ & 0.038 & $(0.217)$ \\
\hline Protection at Clinics & $-0.453^{*}$ & $(0.243)$ & $-0.424^{\star \star}$ & $(0.215)$ \\
\hline Conception Prior to Age 15 & $0.707^{\star}$ & $(0.397)$ & -0.188 & $(0.356)$ \\
\hline Smoke During Pregnancy & -0.408 & $(0.282)$ & $-0.738^{\star \star \star}$ & $(0.230)$ \\
\hline Drink During Pregnancy & $1.057^{* * *}$ & $(0.406)$ & -0.553 & $(0.417)$ \\
\hline Drug Use During Pregnancy & -0.041 & $(0.540)$ & $-0.725^{\star}$ & $(0.412)$ \\
\hline Constant & -0.796 & $(1.382)$ & $3.878^{\star \star \star}$ & $(1.226)$ \\
\hline Observations & 1020 & & 1020 & \\
\hline
\end{tabular}

${ }^{\star \star \star} p<0.01,{ }^{\star \star} p<0.05,{ }^{*} p<0.1$. 
Table 4

Effects of Teenage Childbearing on Early Life Outcomes

\begin{tabular}{|c|c|c|c|c|c|c|c|c|}
\hline $\begin{array}{l}\text { Specification } \\
\text { Sample } \\
\text { Fixed Effects }\end{array}$ & $\begin{array}{l}\text { OLS } \\
\text { Birth/No } \\
\text { Birth } \\
\text { No }\end{array}$ & $\begin{array}{l}\text { OLS } \\
\text { Birth/No } \\
\text { Birth } \\
\text { Yes }\end{array}$ & $\begin{array}{l}\text { 2SLS } \\
\text { B/A/M } \\
\text { No }\end{array}$ & $\begin{array}{l}2 S L S \\
\text { B/A/M } \\
\text { Yes }\end{array}$ & $\begin{array}{c}\text { OLS } \\
\text { Birth or } \\
\text { Miscarriage } \\
\text { No }\end{array}$ & $\begin{array}{l}\text { OLS } \\
\text { Birth or } \\
\text { Miscarriage } \\
\text { Yes }\end{array}$ & $\begin{array}{c}\text { OLS } \\
\text { Birth or } \\
\text { Miscarriage } \\
\text { No } \\
\text { Late Miscarriages }\end{array}$ & $\begin{array}{c}\text { OLS } \\
\text { Birth or } \\
\text { Miscarriage } \\
\text { Yes } \\
\text { Late Miscarriages }\end{array}$ \\
\hline Diploma & $\begin{array}{l}-0.182^{\star \star *} \\
(0.042)\end{array}$ & $\begin{array}{l}-0.156 * \star * \\
(0.035)\end{array}$ & $\begin{array}{c}0.012 \\
(0.070)\end{array}$ & $\begin{array}{c}0.048 \\
(0.073)\end{array}$ & $\begin{array}{l}-0.087 \\
(0.053)\end{array}$ & $\begin{array}{l}-0.092^{\star *} \\
(0.044)\end{array}$ & $\begin{array}{l}-0.024 \\
(0.062)\end{array}$ & $\begin{array}{l}-0.080 \\
(0.057)\end{array}$ \\
\hline $\begin{array}{l}\text { Observations } \\
\text { Community Dummies P-Value } \\
\text { Hausman Test P-Value }\end{array}$ & 968 & $\begin{array}{c}968 \\
0.023 \\
0.055\end{array}$ & 968 & $\begin{array}{c}967 \\
0.002 \\
0.090\end{array}$ & 711 & $\begin{array}{c}711 \\
0.096 \\
0.225\end{array}$ & 654 & $\begin{array}{c}654 \\
0.764 \\
0.588\end{array}$ \\
\hline GED & $\begin{array}{l}-0.003 \\
(0.037)\end{array}$ & $\begin{array}{c}0.017 \\
(0.024)\end{array}$ & $\begin{array}{l}-0.050 \\
(0.066)\end{array}$ & $\begin{array}{l}-0.059 \\
(0.071)\end{array}$ & $\begin{array}{l}-0.024 \\
(0.048)\end{array}$ & $\begin{array}{c}0.003 \\
(0.034)\end{array}$ & $\begin{array}{l}-0.093 \\
(0.060)\end{array}$ & $\begin{array}{l}-0.021 \\
(0.044)\end{array}$ \\
\hline $\begin{array}{l}\text { Observations } \\
\text { Community Dummies P-Value } \\
\text { Hausman Test P-Value }\end{array}$ & 970 & $\begin{array}{c}970 \\
0.052 \\
0.176\end{array}$ & 970 & $\begin{array}{c}969 \\
0.011 \\
0.730\end{array}$ & 713 & $\begin{array}{c}713 \\
0.157 \\
0.208\end{array}$ & 655 & $\begin{array}{c}655 \\
0.913 \\
0.369\end{array}$ \\
\hline Education & $\begin{array}{l}-0.961^{\star \star \star} \\
(0.160)\end{array}$ & $\begin{array}{c}-0.823^{\star \star \star} \\
(0.118)\end{array}$ & $\begin{array}{l}-0.099 \\
(0.290)\end{array}$ & $\begin{array}{c}0.149 \\
(0.286)\end{array}$ & $\begin{array}{l}-0.513^{\star \star} \\
(0.212)\end{array}$ & $\begin{array}{l}-0.121 \\
(0.166)\end{array}$ & $\begin{array}{l}-0.277 \\
(0.251)\end{array}$ & $\begin{array}{c}0.097 \\
(0.204)\end{array}$ \\
\hline $\begin{array}{l}\text { Observations } \\
\text { Community Dummies P-Value } \\
\text { Hausman Test P-Value }\end{array}$ & 971 & $\begin{array}{c}971 \\
0.000 \\
0.004\end{array}$ & 971 & $\begin{array}{c}970 \\
0.000 \\
0.000\end{array}$ & 714 & $\begin{array}{c}714 \\
0 \\
0.002\end{array}$ & 656 & $\begin{array}{c}656 \\
0.023 \\
0.005\end{array}$ \\
\hline
\end{tabular}

Controls: Age, Conception before 15, smoke, drink, or take drugs during pregnancy. ${ }^{* \star} p<0.01,{ }^{\star *} p<0.05,{ }^{*} p<0.1$ Notes: No Birth includes abortions and miscarriages, B/A/M includes births, abortions, and miscarriages. Each cell represents a separate regression 
Table 4 (continued)

Effects of Teenage Childbearing on Early Life Outcomes

\begin{tabular}{|c|c|c|c|c|c|c|c|c|}
\hline $\begin{array}{l}\text { Specification } \\
\text { Sample } \\
\text { Fixed Effects }\end{array}$ & $\begin{array}{l}\text { OLS } \\
\text { Birth/No } \\
\text { Birth } \\
\text { No }\end{array}$ & $\begin{array}{l}\text { OLS } \\
\text { Birth/No } \\
\text { Birth } \\
\text { Yes }\end{array}$ & $\begin{array}{l}2 \mathrm{SLS} \\
\mathrm{B} / \mathrm{A} / \mathrm{M} \\
\mathrm{No}\end{array}$ & $\begin{array}{l}2 \text { SLS } \\
\text { B/A/M } \\
\text { Yes }\end{array}$ & $\begin{array}{c}\text { OLS } \\
\text { Birth or } \\
\text { Miscarriage } \\
\text { No }\end{array}$ & $\begin{array}{c}\text { OLS } \\
\text { Birth or } \\
\text { Miscarriage } \\
\text { Yes }\end{array}$ & $\begin{array}{c}\text { OLS } \\
\text { Birth or } \\
\text { Miscarriage } \\
\text { No } \\
\text { Late Miscarriages }\end{array}$ & $\begin{array}{c}\text { OLS } \\
\text { Birth or } \\
\text { Miscarriage } \\
\text { Yes } \\
\text { Late Miscarriages }\end{array}$ \\
\hline Welfare & $\begin{array}{l}0.131^{\star \star \star} \\
(0.037)\end{array}$ & $\begin{array}{l}0.085^{\star \star \star} \\
(0.027)\end{array}$ & $\begin{array}{c}0.083 \\
(0.070)\end{array}$ & $\begin{array}{l}-0.008 \\
(0.061)\end{array}$ & $\begin{array}{l}0.110^{*} \\
(0.056)\end{array}$ & $\begin{array}{c}0.026 \\
(0.042)\end{array}$ & $\begin{array}{c}0.083 \\
(0.079)\end{array}$ & $\begin{array}{l}-0.003 \\
(0.055)\end{array}$ \\
\hline $\begin{array}{l}\text { Observations } \\
\text { Community Dummies P-Value } \\
\text { Hausman Test P-Value }\end{array}$ & 970 & $\begin{array}{c}970 \\
0 \\
0.147\end{array}$ & 970 & $\begin{array}{c}969 \\
0.000 \\
0.001\end{array}$ & 713 & $\begin{array}{l}713 \\
0.001 \\
0.015\end{array}$ & 655 & $\begin{array}{l}655 \\
0.099 \\
0.096\end{array}$ \\
\hline Total Income & $\begin{array}{l}-2.547^{\star \star} \\
(1.009)\end{array}$ & $\begin{array}{l}-2.697^{\star \star} \\
(1.183)\end{array}$ & $\begin{array}{l}-1.515 \\
(2.309)\end{array}$ & $\begin{array}{l}-1.300 \\
(2.272)\end{array}$ & $\begin{array}{l}-1.938 \\
(1.518)\end{array}$ & $\begin{array}{l}-2.710 \\
(1.745)\end{array}$ & $\begin{array}{l}-2.031^{*} \\
(1.205)\end{array}$ & $\begin{array}{l}-2.952^{\star *} \\
(1.227)\end{array}$ \\
\hline $\begin{array}{l}\text { Observations } \\
\text { Community Dummies P-Value } \\
\text { Hausman Test P-Value }\end{array}$ & 918 & $\begin{array}{c}918 \\
0.321 \\
0.802\end{array}$ & 918 & $\begin{array}{c}917 \\
0.144 \\
0.603\end{array}$ & 670 & $\begin{array}{c}670 \\
0.071 \\
0.575\end{array}$ & 616 & $\begin{array}{c}616 \\
0.942 \\
0.731\end{array}$ \\
\hline Total Wages & $\begin{array}{l}-3.546^{\star \star *} \\
(1.025)\end{array}$ & $\begin{array}{l}-2.487^{\star *} \\
(1.142)\end{array}$ & $\begin{array}{l}-1.905 \\
(2.200)\end{array}$ & $\begin{array}{l}-1.064 \\
(1.980)\end{array}$ & $\begin{array}{l}-2.572^{\star} \\
(1.469)\end{array}$ & $\begin{array}{l}-2.375 \\
(1.664)\end{array}$ & $\begin{array}{l}-2.254^{\star *} \\
(1.095)\end{array}$ & $\begin{array}{l}-2.846^{\star \star} \\
(1.099)\end{array}$ \\
\hline $\begin{array}{l}\text { Observations } \\
\text { Community Dummies P-Value }\end{array}$ & 936 & $\begin{array}{c}936 \\
0.074\end{array}$ & 936 & $\begin{array}{c}935 \\
0.018\end{array}$ & 688 & $\begin{array}{c}688 \\
0.019\end{array}$ & 632 & $\begin{array}{c}632 \\
0.846\end{array}$ \\
\hline Hausman Test P-Value & & 0.433 & & 0.379 & & 0.621 & & 0.805 \\
\hline
\end{tabular}

Controls: Age, Conception before 15, smoke, drink, or take drugs during pregnancy. ${ }^{\star \star \star} p<0.01,{ }^{* \star} p<0.05,{ }^{*} p<0.1$ Notes:

No Birth includes abortions and miscarriages, B/A/M includes births, abortions, and miscarriages. Each cell represents a

separate regression 
Table 5

Effects of Teenage Childbearing on Early Life Outcomes

Individuals Using Birth Control

\begin{tabular}{|c|c|c|c|c|}
\hline $\begin{array}{l}\text { Specification } \\
\text { Sample }\end{array}$ & $\begin{array}{c}\text { OLS } \\
\text { Birth or } \\
\text { Miscarriage } \\
\text { Use Birth Control } \\
\text { No }\end{array}$ & $\begin{array}{c}\text { OLS } \\
\text { Birth or } \\
\text { Miscarriage } \\
\text { Use Birth Control } \\
\text { Yes }\end{array}$ & $\begin{array}{c}\text { OLS } \\
\text { Birth or } \\
\text { Miscarriage } \\
\text { Use Birth Control } \\
\text { Late Miscarriages } \\
\text { No }\end{array}$ & $\begin{array}{c}\text { OLS } \\
\text { Birth or } \\
\text { Miscarriage } \\
\text { Use Birth Control } \\
\text { Late Miscarriages } \\
\text { Yes }\end{array}$ \\
\hline Diploma & $\begin{array}{c}-0.188^{\star * *} \\
(0.065)\end{array}$ & $\begin{array}{l}-0.119 \\
(0.079)\end{array}$ & $\begin{array}{l}-0.093 \\
(0.083)\end{array}$ & $\begin{array}{l}-0.073 \\
(0.124)\end{array}$ \\
\hline $\begin{array}{l}\text { Observations } \\
\text { Community Dummies P-Value } \\
\text { Hausman Test P-Value }\end{array}$ & 273 & $\begin{array}{l}273 \\
0.821 \\
0.593\end{array}$ & 249 & $\begin{array}{l}249 \\
0.880 \\
0.477\end{array}$ \\
\hline GED & $\begin{array}{c}0.051 \\
(0.066)\end{array}$ & $\begin{array}{c}0.048 \\
(0.071)\end{array}$ & $\begin{array}{c}0.038 \\
(0.073)\end{array}$ & $\begin{array}{c}0.003 \\
(0.102)\end{array}$ \\
\hline $\begin{array}{l}\text { Observations } \\
\text { Community Dummies P-Value } \\
\text { Hausman Test P-Value }\end{array}$ & 274 & $\begin{array}{l}274 \\
0.382 \\
0.585\end{array}$ & 249 & $\begin{array}{l}249 \\
0.345 \\
0.505\end{array}$ \\
\hline $\begin{array}{l}\text { Education } \\
\text { Observations } \\
\text { Community Dummies P-Value } \\
\text { Hausman Test P-Value }\end{array}$ & $\begin{array}{c}-0.501 \\
(0.320) \\
275\end{array}$ & $\begin{array}{c}-0.084 \\
(0.415) \\
275 \\
0.461 \\
0.089\end{array}$ & $\begin{array}{c}0.057 \\
(0.464) \\
250\end{array}$ & $\begin{array}{c}0.446 \\
(0.556) \\
250 \\
0.186 \\
0.012\end{array}$ \\
\hline $\begin{array}{l}\text { Welfare } \\
\text { Observations } \\
\text { Community Dummies P-Value } \\
\text { Hausman Test P-Value }\end{array}$ & $\begin{array}{c}0.066 \\
(0.066) \\
275\end{array}$ & $\begin{array}{c}0.005 \\
(0.080) \\
275 \\
0.033 \\
0.076\end{array}$ & $\begin{array}{c}0.053 \\
(0.077) \\
250\end{array}$ & $\begin{array}{c}-0.022 \\
(0.115) \\
250 \\
0.038 \\
0.468\end{array}$ \\
\hline Total Income & $\begin{array}{c}-4.320^{\star \star} \\
(1.663)\end{array}$ & $\begin{array}{l}-1.100 \\
(1.126)\end{array}$ & $\begin{array}{c}-4.433^{\star \star} \\
(1.838)\end{array}$ & $\begin{array}{c}-3.019 \star * \\
(1.236)\end{array}$ \\
\hline $\begin{array}{l}\text { Observations } \\
\text { Community Dummies P-Value } \\
\text { Hausman Test P-Value }\end{array}$ & 255 & $\begin{array}{c}255 \\
0 \\
0.027\end{array}$ & 231 & $\begin{array}{c}231 \\
0 \\
0.104\end{array}$ \\
\hline Total Wages & $\begin{array}{c}-5.146^{\star \star *} \\
(1.620)\end{array}$ & $\begin{array}{l}-1.417 \\
(1.338)\end{array}$ & $\begin{array}{c}-4.319^{* \star *} \\
(1.310)\end{array}$ & $\begin{array}{c}-3.473^{\star \star} \\
(1.376)\end{array}$ \\
\hline $\begin{array}{l}\text { Observations } \\
\text { Community Dummies P-Value } \\
\text { Hausman Test P-Value }\end{array}$ & 265 & $\begin{array}{l}265 \\
0.001 \\
0.029\end{array}$ & 240 & $\begin{array}{l}240 \\
0.047 \\
0.204\end{array}$ \\
\hline
\end{tabular}

Controls: Age, Conception before 15, smoke, drink, or take drugs during pregnancy. ${ }^{\star \star \star} p<0.01,{ }^{\star \star} p<0.05,{ }^{*} p<0.1$. Each cell represents a separate regression 
Table 6

Summary of Results Stratified by Birth Control Choice

\begin{tabular}{|ll|ll|}
\hline & & $\begin{array}{l}\text { Lower Bound } \\
\text { B/M, FE }\end{array}$ & $\begin{array}{l}\text { Upper Bound } \\
\text { B/LM, FE }\end{array}$ \\
\hline High School Diploma & Birth Control & -0.119 & -0.073 \\
& No Birth Control & -0.073 & -0.061 \\
\hline GED & Birth Control & 0.048 & 0.003 \\
& No Birth Control & -0.018 & -0.025 \\
\hline Years of Education & Birth Control & -0.084 & 0.446 \\
& No Birth Control & -0.057 & 0.036 \\
\hline Welfare Receipt & Birth Control & 0.005 & -0.022 \\
& No Birth Control & 0.064 & 0.062 \\
\hline Wages & Birth Control & -1.100 & $-3.019^{\star \star}$ \\
& No Birth Control & -3.120 & -2.688 \\
\hline Total Income & Birth Control & -1.417 & $-3.473^{\star \star}$ \\
& No Birth Control & -1.986 & -2.072 \\
\hline
\end{tabular}

Notes: Each cell represents a separate regression. All results can be found in Table 4 or Table $7 \mathrm{~A}$. $\mathrm{B} / \mathrm{M}=$ birth vs. miscarriage comparison. $\mathrm{B} / \mathrm{LM}=$ birth vs. late miscarriage comparison. $\mathrm{FE}=$ community fixed effects are controlled. $\mathrm{IV}=$ instrumental variables with miscarriage as the instrument 
Table 7

Results Summary

\begin{tabular}{|l|l|l|l|l|}
\hline & Lower Bound & Upper Bound & Tight Lower Bound & Tight Upper Bound \\
\hline & Birth/No Birth & IV, FE & B/M, FE & B/LM, FE \\
\hline High School Diploma & $-0.182^{\star \star *}$ & 0.048 & $-0.092^{\star \star}$ & -0.080 \\
\hline GED & -0.003 & -0.059 & 0.003 & -0.021 \\
\hline Years of Education & $-0.961^{\star \star *}$ & 0.149 & -0.121 & 0.097 \\
\hline Welfare Receipt & $0.131^{\star \star *}$ & -0.008 & 0.026 & -0.003 \\
\hline Wages & $-2.547^{\star *}$ & -1.300 & -2.710 & $-2.952^{\star *}$ \\
\hline Total Income & $-3.546^{\star \star *}$ & -1.064 & -2.375 & $-2.846^{\star \star}$ \\
\hline
\end{tabular}

Notes: Each cell represents a separate regression. All results can be found in Table $4 . \mathrm{B} / \mathrm{M}=$ birth vs. miscarriage comparison. $\mathrm{B} / \mathrm{LM}=$ birth vs. late miscarriage comparison. $\mathrm{FE}=$ community fixed effects are controlled. $\mathrm{IV}=$ instrumental variables with miscarriage as the instrument.

${ }^{* \star *} p<0.01,{ }^{* \star} p<0.05,{ }^{*} p<0.1$. 
Appendix Tables:

Table 1A

Summary Statistics: National Longitudinal Study of Adolescent Health

Live Births

\begin{tabular}{|c|c|c|c|c|c|}
\hline$\underline{\text { Variable }}$ & $\underline{\text { Obs }}$ & Mean & $\underline{\text { Std Dev }}$ & $\underline{\text { Min }}$ & $\underline{\operatorname{Max}}$ \\
\hline \multicolumn{6}{|l|}{ Outcomes } \\
\hline High School Diploma & 614 & 0.61 & 0.49 & 0 & 1 \\
\hline GED & 614 & 0.14 & 0.35 & 0 & 1 \\
\hline Years of Schooling & 616 & 11.89 & 1.72 & 8 & 20 \\
\hline Welfare Receipt & 615 & 0.17 & 0.38 & 0 & 1 \\
\hline Total Income & 578 & 10911 & 10170 & 0 & 83000 \\
\hline $\begin{array}{l}\text { Total Labor Income } \\
\text { Individual Characteristics }\end{array}$ & 595 & 8331 & 9676 & 0 & 83000 \\
\hline$\overline{\text { Age }}$ & 616 & 21.79 & 1.63 & 18 & 27 \\
\hline White & 616 & 0.42 & 0.49 & 0 & 1 \\
\hline Black & 616 & 0.37 & 0.48 & 0 & 1 \\
\hline Hispanic & 616 & 0.18 & 0.38 & 0 & 1 \\
\hline PPVT Test Score & 616 & 94.54 & 12.16 & 54 & 130 \\
\hline General Health & 616 & 2.41 & 0.95 & 1 & 5 \\
\hline \multicolumn{6}{|l|}{ Family Characteristics } \\
\hline$\overline{\text { Parent Education }}$ & 616 & 12.43 & 2.00 & 0 & 17 \\
\hline Family Income & 616 & 32.36 & 25.81 & 0 & 426 \\
\hline Parent Married & 616 & 0.46 & 0.50 & 0 & 1 \\
\hline Parent Religiosity & 616 & 23.19 & 17.70 & 0 & 50 \\
\hline Mother Work & 616 & 0.66 & 0.42 & 0 & 1 \\
\hline Parent Missing Data & 616 & 0.43 & 0.50 & 0 & 1 \\
\hline \multicolumn{6}{|l|}{ Pregnancy Variables } \\
\hline$\overline{\text { Used Birth Control }}$ & 601 & 0.39 & 0.49 & 0 & 1 \\
\hline Age Pregnancy Ended & 616 & 17.33 & 1.05 & 14 & 19 \\
\hline Conception Before Age 15 & 616 & 0.07 & 0.25 & 0 & 1 \\
\hline Smoke During Pregnancy & 605 & 0.15 & 0.36 & 0 & 1 \\
\hline Drink During Pregnancy & 602 & 0.03 & 0.17 & 0 & 1 \\
\hline Drugs During Pregnancy & 603 & 0.03 & 0.17 & 0 & 1 \\
\hline Weeks Pregnant & 588 & 33.20 & 11.67 & 0 & 40 \\
\hline \multicolumn{6}{|l|}{ Community Variables } \\
\hline$\overline{\text { Median Income (Comm) }}$ & 616 & 28.16 & 7.21 & 14 & 48 \\
\hline$\%$ Poverty (Comm) & 616 & 15.81 & 7.68 & 4 & 39 \\
\hline$\%$ Black (Comm & 616 & 0.18 & 0.16 & 0 & 1 \\
\hline Rural (Comm) & 611 & 0.27 & 0.44 & 0 & 1 \\
\hline Urban (Comm) & 611 & 0.41 & 0.49 & 0 & 1 \\
\hline \multicolumn{6}{|l|}{ Violent Crime Per 100K (1000s) } \\
\hline (Comm) & 604 & 0.90 & 0.65 & 0 & 3 \\
\hline $\begin{array}{l}\text { Total Crime Per 100k (1000s) (Comm) } \\
\text { Monthly AFDC Per Recipient (State) }\end{array}$ & $\begin{array}{l}604 \\
616\end{array}$ & $\begin{array}{r}6.08 \\
108.28\end{array}$ & $\begin{array}{r}2.71 \\
48.92\end{array}$ & $\begin{array}{r}0 \\
42\end{array}$ & $\begin{array}{r}14 \\
214\end{array}$ \\
\hline Parental Consent Law (State) & 616 & 0.63 & 0.48 & 0 & 1 \\
\hline Abortion Funding (State) & 616 & 0.28 & 0.45 & 0 & 1 \\
\hline Proportion Miscarried (Comm Sample) & 616 & 13.71 & 15.03 & 0 & 100 \\
\hline Proportion Abortion (Comm Sample) & 616 & 22.60 & 19.30 & 0 & 100 \\
\hline
\end{tabular}


Table 2A

Summary Statistics: National Longitudinal Study of Adolescent Health Miscarriages

\begin{tabular}{|c|c|c|c|c|c|}
\hline$\underline{\text { Variable }}$ & $\underline{\text { Obs }}$ & Mean & Std Dev & $\underline{\text { Min }}$ & $\underline{\operatorname{Max}}$ \\
\hline \multicolumn{6}{|l|}{ Outcomes } \\
\hline High School Diploma & 162 & 0.68 & 0.47 & 0 & 1 \\
\hline GED & 163 & 0.14 & 0.35 & 0 & 1 \\
\hline Years of Schooling & 163 & 12.07 & 1.81 & 7 & 20 \\
\hline Welfare Receipt & 163 & 0.12 & 0.32 & 0 & 1 \\
\hline Total Income & 156 & 13642 & 19941 & 0 & 200000 \\
\hline $\begin{array}{l}\text { Total Labor Income } \\
\text { Individual Characteristics }\end{array}$ & 157 & 10398 & 16508 & 0 & 175000 \\
\hline Age & 163 & 21.45 & 1.51 & 18 & 25 \\
\hline White & 163 & 0.47 & 0.50 & 0 & 1 \\
\hline Black & 163 & 0.27 & 0.45 & 0 & 1 \\
\hline Hispanic & 163 & 0.23 & 0.42 & 0 & 1 \\
\hline PPVT Test Score & 163 & 95.18 & 13.62 & 63 & 132 \\
\hline General Health & 163 & 2.40 & 0.97 & 1 & 5 \\
\hline \multicolumn{6}{|l|}{ Family Characteristics } \\
\hline Parent Education & 163 & 12.79 & 2.09 & 8 & 17 \\
\hline Family Income & 163 & 35.54 & 27.71 & 0 & 233 \\
\hline Parent Married & 163 & 0.58 & 0.49 & 0 & 1 \\
\hline Parent Religiosity & 163 & 26.45 & 19.26 & 0 & 50 \\
\hline Mother Work & 163 & 0.63 & 0.45 & 0 & 1 \\
\hline Parent Missing Data & 163 & 0.36 & 0.48 & 0 & 1 \\
\hline \multicolumn{6}{|l|}{ Pregnancy Variables } \\
\hline Used Birth Control & 157 & 0.36 & 0.48 & 0 & 1 \\
\hline Age Pregnancy Ended & 163 & 17.26 & 1.11 & 13 & 19 \\
\hline Conception Before Age 15 & 163 & 0.07 & 0.26 & 0 & 1 \\
\hline Smoke During Pregnancy & 160 & 0.28 & 0.45 & 0 & 1 \\
\hline Drink During Pregnancy & 160 & 0.10 & 0.30 & 0 & 1 \\
\hline Drugs During Pregnancy & 159 & 0.10 & 0.30 & 0 & 1 \\
\hline Weeks Pregnant & 156 & 12.78 & 11.23 & 0 & 40 \\
\hline \multicolumn{6}{|l|}{ Community Variables } \\
\hline$\overline{\text { Median Income (Comm) }}$ & 163 & 29.23 & 7.70 & 14 & 49 \\
\hline$\%$ Poverty (Comm) & 163 & 14.85 & 7.83 & 4 & 36 \\
\hline$\%$ Black (Comm & 163 & 0.16 & 0.17 & 0 & 1 \\
\hline Rural (Comm) & 162 & 0.35 & 0.48 & 0 & 1 \\
\hline Urban (Comm) & 162 & 0.38 & 0.49 & 0 & 1 \\
\hline Violent Crime Per 100K (1000s) (Comm) & 161 & 0.91 & 0.76 & 0 & 3 \\
\hline Total Crime Per 100k (1000s) (Comm) & 161 & 6.13 & 3.19 & 1 & 17 \\
\hline Monthly AFDC Per Recipient (State) & 163 & 119.17 & 50.28 & 42 & 214 \\
\hline Parental Consent Law (State) & 163 & 0.46 & 0.50 & 0 & 1 \\
\hline Abortion Funding (State) & 163 & 0.37 & 0.48 & 0 & 1 \\
\hline Proportion Miscarried (Comm Sample) & 163 & 22.65 & 21.12 & 0 & 100 \\
\hline Proportion Abortion (Comm Sample) & 163 & 24.87 & 20.98 & 0 & 100 \\
\hline
\end{tabular}


Table 3A

Summary Statistics: National Longitudinal Study of Adolescent Health Abortions

\begin{tabular}{|c|c|c|c|c|c|}
\hline Variable & Obs & Mean & $\frac{\text { Std }}{\text { Dev }}$ & $\underline{\text { Min }}$ & $\underline{\text { Max }}$ \\
\hline \multicolumn{6}{|l|}{ Outcomes } \\
\hline$\overline{\text { High School Diploma }}$ & 262 & 0.82 & 0.39 & 0 & 1 \\
\hline GED & 262 & 0.11 & 0.32 & 0 & 1 \\
\hline Years of Schooling & 262 & 13.22 & 1.93 & 7 & 19 \\
\hline Welfare Receipt & 262 & 0.06 & 0.23 & 0 & 1 \\
\hline Total Income & 253 & 13123 & 13924 & 0 & 100000 \\
\hline Total Labor Income & 254 & 10907 & 11248 & 0 & 60000 \\
\hline \multicolumn{6}{|l|}{ Individual Characteristics } \\
\hline Age & 262 & 21.63 & 1.76 & 18 & 25 \\
\hline White & 262 & 0.43 & 0.50 & 0 & 1 \\
\hline Black & 262 & 0.33 & 0.47 & 0 & 1 \\
\hline Hispanic & 262 & 0.15 & 0.35 & 0 & 1 \\
\hline PPVT Test Score & 262 & 100.06 & 12.50 & 61 & 131 \\
\hline General Health & 262 & 2.33 & 0.90 & 1 & 4 \\
\hline \multicolumn{6}{|l|}{ Family Characteristics } \\
\hline Parent Education & 262 & 13.43 & 2.35 & 8 & 17 \\
\hline Family Income & 262 & 44.25 & 27.46 & 0 & 200 \\
\hline Parent Married & 262 & 0.56 & 0.50 & 0 & 1 \\
\hline Parent Religiosity & 262 & 23.06 & 18.47 & 0 & 50 \\
\hline Mother Work & 262 & 0.78 & 0.37 & 0 & 1 \\
\hline Parent Missing Data & 262 & 0.29 & 0.45 & 0 & 1 \\
\hline \multicolumn{6}{|l|}{ Pregnancy Variables } \\
\hline Used Birth Control & 259 & 0.42 & 0.49 & 0 & 1 \\
\hline Age Pregnancy Ended & 262 & 17.17 & 1.19 & 14 & 19 \\
\hline Conception Before Age 15 & 262 & 0.11 & 0.32 & 0 & 1 \\
\hline Smoke During Pregnancy & 260 & 0.26 & 0.44 & 0 & 1 \\
\hline Drink During Pregnancy & 260 & 0.21 & 0.41 & 0 & 1 \\
\hline Drugs During Pregnancy & 261 & 0.16 & 0.36 & 0 & 1 \\
\hline Weeks Pregnant & 255 & 9.81 & 5.62 & 0 & 40 \\
\hline \multicolumn{6}{|l|}{ Community Variables } \\
\hline Median Income (Comm) & 262 & 31.81 & 7.92 & 14 & 49 \\
\hline \% Poverty (Comm) & 262 & 13.30 & 6.59 & 4 & 36 \\
\hline$\%$ Black (Comm & 262 & 0.15 & 0.15 & 0 & 1 \\
\hline Rural (Comm) & 259 & 0.17 & 0.38 & 0 & 1 \\
\hline Urban (Comm) & 259 & 0.37 & 0.48 & 0 & 1 \\
\hline Violent Crime Per 100K (1000s) (Comm) & 262 & 0.95 & 0.74 & 0 & 3 \\
\hline Total Crime Per 100k (1000s) (Comm) & 262 & 6.21 & 2.67 & 1 & 14 \\
\hline Monthly AFDC Per Recipient (State) & 262 & 129.22 & 52.31 & 42 & 214 \\
\hline Parental Consent Law (State) & 262 & 0.46 & 0.50 & 0 & 1 \\
\hline Abortion Funding (State) & 262 & 0.48 & 0.50 & 0 & 1 \\
\hline Proportion Miscarried (Comm Sample) & 262 & 15.47 & 18.82 & 0 & 100 \\
\hline Proportion Abortion (Comm Sample) & 262 & 31.64 & 23.72 & 0 & 100 \\
\hline
\end{tabular}


Table 4A

Summary Statistics: National Longitudinal Study of Adolescent Health Late Miscarriages

\begin{tabular}{|c|c|c|c|c|c|}
\hline$\underline{\text { Variable }}$ & Obs & Mean & $\underline{\text { Std Dev }}$ & $\underline{\text { Min }}$ & $\underline{\text { Max }}$ \\
\hline \multicolumn{6}{|l|}{ Outcomes } \\
\hline High School Diploma & 102 & 0.65 & 0.48 & 0 & 1 \\
\hline GED & 102 & 0.19 & 0.39 & 0 & 1 \\
\hline Years of Schooling & 102 & 11.85 & 1.76 & 7 & 16 \\
\hline Welfare Receipt & 102 & 0.15 & 0.36 & 0 & 1 \\
\hline Total Income & 99 & 14066 & 13990 & 0 & 110000 \\
\hline Total Labor Income & 98 & 10567 & 9574 & 0 & 36000 \\
\hline \multicolumn{6}{|l|}{ Individual Characteristics } \\
\hline Age & 102 & 21.60 & 1.60 & 18 & 25 \\
\hline White & 102 & 0.48 & 0.50 & 0 & 1 \\
\hline Black & 102 & 0.25 & 0.43 & 0 & 1 \\
\hline Hispanic & 102 & 0.23 & 0.42 & 0 & 1 \\
\hline PPVT Test Score & 102 & 95.53 & 13.15 & 67 & 121 \\
\hline General Health & 102 & 2.53 & 0.94 & 1 & 5 \\
\hline \multicolumn{6}{|l|}{ Family Characteristics } \\
\hline Parent Education & 102 & 12.86 & 2.13 & 8 & 17 \\
\hline Family Income & 102 & 36.55 & 31.36 & 0 & 233 \\
\hline Parent Married & 102 & 0.60 & 0.49 & 0 & 1 \\
\hline Parent Religiosity & 102 & 28.82 & 19.36 & 0 & 50 \\
\hline Mother Work & 102 & 0.63 & 0.44 & 0 & 1 \\
\hline Parent Missing Data & 102 & 0.39 & 0.49 & 0 & 1 \\
\hline \multicolumn{6}{|l|}{ Pregnancy Variables } \\
\hline Used Birth Control & 96 & 0.32 & 0.47 & 0 & 1 \\
\hline Age Pregnancy Ended & 102 & 17.30 & 1.06 & 13 & 19 \\
\hline Conception Before Age 15 & 102 & 0.06 & 0.24 & 0 & 1 \\
\hline Smoke During Pregnancy & 100 & 0.33 & 0.47 & 0 & 1 \\
\hline Drink During Pregnancy & 99 & 0.12 & 0.33 & 0 & 1 \\
\hline Drugs During Pregnancy & 99 & 0.11 & 0.32 & 0 & 1 \\
\hline Weeks Pregnant & 95 & 18.56 & 10.92 & 8 & 40 \\
\hline \multicolumn{6}{|l|}{ Community Variables } \\
\hline Median Income (Comm) & 102 & 29.42 & 8.02 & 14 & 49 \\
\hline$\%$ Poverty (Comm) & 102 & 14.94 & 8.42 & 4 & 36 \\
\hline \% Black (Comm & 102 & 0.15 & 0.17 & 0 & 1 \\
\hline Rural (Comm) & 101 & 0.34 & 0.47 & 0 & 1 \\
\hline Urban (Comm) & 101 & 0.41 & 0.49 & 0 & 1 \\
\hline Violent Crime Per 100K (1000s) (Comm) & 100 & 0.93 & 0.83 & 0 & 3 \\
\hline Total Crime Per 100k (1000s) (Comm) & 100 & 5.87 & 3.33 & 1 & 17 \\
\hline Monthly AFDC Per Recipient (State) & 102 & 126.05 & 51.24 & 42 & 214 \\
\hline $\begin{array}{l}\text { Medicaid Proportion Receiving AFDC (State) } \\
\% \text { College Graduates (Age }>25 \text { ) }\end{array}$ & 102 & 0.39 & 0.09 & 0.2 & 0.6 \\
\hline (Community) & 102 & 0.25 & 0.08 & 0.1 & 0.4 \\
\hline Sex Ratio (Ages 17-21) (Community) & 102 & 0.97 & 0.14 & 0.6 & 1.2 \\
\hline Parental Consent Law (State) & 102 & 0.43 & 0.50 & 0 & 1 \\
\hline Abortion Funding (State) & 102 & 0.44 & 0.50 & 0 & 1 \\
\hline Proportion Miscarried (Comm Sample) & 102 & 22.35 & 21.72 & 0 & 100 \\
\hline Proportion Abortion (Comm Sample) & 102 & 25.32 & 20.58 & 0 & 100 \\
\hline
\end{tabular}


Table 5A

Summary Statistics: National Longitudinal Study of Adolescent Health Early Miscarriages

\begin{tabular}{|c|c|c|c|c|c|}
\hline Variable & Obs & Mean & $\underline{\text { Std Dev }}$ & Min & $\underline{\text { Max }}$ \\
\hline \multicolumn{6}{|l|}{ Outcomes } \\
\hline High School Diploma & 60 & 0.73 & 0.45 & 0 & 1 \\
\hline GED & 61 & 0.07 & 0.25 & 0 & 1 \\
\hline Years of Schooling & 61 & 12.44 & 1.85 & 8 & 20 \\
\hline Welfare Receipt & 61 & 0.07 & 0.25 & 0 & 1 \\
\hline Total Income & 57 & 12906 & 27518 & 0 & 200000 \\
\hline Total Labor Income & 59 & 10119 & 24073 & 0 & 175000 \\
\hline \multicolumn{6}{|l|}{ Individual Characteristics } \\
\hline Age & 61 & 21.20 & 1.33 & 18 & 24 \\
\hline White & 61 & 0.44 & 0.50 & 0 & 1 \\
\hline Black & 61 & 0.31 & 0.47 & 0 & 1 \\
\hline Hispanic & 61 & 0.23 & 0.42 & 0 & 1 \\
\hline PPVT Test Score & 61 & 94.59 & 14.46 & 63 & 132 \\
\hline General Health & 61 & 2.18 & 0.99 & 1 & 5 \\
\hline \multicolumn{6}{|l|}{ Family Characteristics } \\
\hline$\overline{\text { Parent Education }}$ & 61 & 12.66 & 2.04 & 8 & 17 \\
\hline Family Income & 61 & 33.85 & 20.33 & 5 & 100 \\
\hline Parent Married & 61 & 0.56 & 0.50 & 0 & 1 \\
\hline Parent Religiosity & 61 & 22.48 & 18.57 & 0 & 50 \\
\hline Mother Work & 61 & 0.63 & 0.46 & 0 & 1 \\
\hline Parent Missing Data & 61 & 0.30 & 0.46 & 0 & 1 \\
\hline \multicolumn{6}{|l|}{ Pregnancy Variables } \\
\hline Used Birth Control & 61 & 0.43 & 0.50 & 0 & 1 \\
\hline Age Pregnancy Ended & 61 & 17.20 & 1.20 & 14 & 19 \\
\hline Conception Before Age 15 & 61 & 0.10 & 0.30 & 0 & 1 \\
\hline Smoke During Pregnancy & 60 & 0.20 & 0.40 & 0 & 1 \\
\hline Drink During Pregnancy & 61 & 0.07 & 0.25 & 0 & 1 \\
\hline Drugs During Pregnancy & 60 & 0.08 & 0.28 & 0 & 1 \\
\hline Weeks Pregnant & 61 & 3.77 & 1.97 & 0 & 7 \\
\hline \multicolumn{6}{|l|}{ Community Variables } \\
\hline$\overline{\text { Median Income (Comm) }}$ & 61 & 28.91 & 7.18 & 16 & 48 \\
\hline$\%$ Poverty (Comm) & 61 & 14.70 & 6.79 & 5 & 36 \\
\hline$\%$ Black (Comm & 61 & 0.18 & 0.18 & 0 & 1 \\
\hline Rural (Comm) & 61 & 0.36 & 0.48 & 0 & 1 \\
\hline Urban (Comm) & 61 & 0.33 & 0.47 & 0 & 1 \\
\hline Violent Crime Per 100K (1000s) (Comm) & 61 & 0.87 & 0.63 & 0 & 3 \\
\hline Total Crime Per 100k (1000s) (Comm) & 61 & 6.57 & 2.91 & 2 & 14 \\
\hline Monthly AFDC Per Recipient (State) & 61 & 107.67 & 46.80 & 42 & 198 \\
\hline Medicaid Proportion Receiving AFDC (State) & 61 & 0.40 & 0.09 & 0.2 & 0.6 \\
\hline$\%$ College Graduates (Age >25) (Community) & 61 & 0.27 & 0.07 & 0.1 & 0.4 \\
\hline Sex Ratio (Ages 17-21) (Community) & 61 & 0.95 & 0.15 & 0.6 & 1.2 \\
\hline Parental Consent Law (State) & 61 & 0.51 & 0.50 & 0 & 1 \\
\hline Abortion Funding (State) & 61 & 0.25 & 0.43 & 0 & 1 \\
\hline Proportion Miscarried (Comm Sample) & 61 & 23.14 & 20.25 & 0 & 100 \\
\hline Proportion Abortion (Comm Sample) & 61 & 24.11 & 21.80 & 0 & 100 \\
\hline
\end{tabular}


Table 6A

Effects of Teenage Childbearing on Early Life Outcomes Individuals Not Using Birth Control

\begin{tabular}{|c|c|c|c|c|}
\hline $\begin{array}{l}\text { Specification } \\
\text { Sample }\end{array}$ & $\begin{array}{c}\text { OLS } \\
\text { Birth or } \\
\text { Miscarriage } \\
\text { No Birth Control }\end{array}$ & $\begin{array}{c}\text { OLS } \\
\text { Birth or } \\
\text { Miscarriage } \\
\text { No Birth Control }\end{array}$ & $\begin{array}{c}\text { OLS } \\
\text { Birth or } \\
\text { Miscarriage } \\
\text { No Birth Control } \\
\text { Late Miscarriages }\end{array}$ & $\begin{array}{c}\text { OLS } \\
\text { Birth or } \\
\text { Miscarriage } \\
\text { No Birth Control } \\
\text { Late Miscarriages }\end{array}$ \\
\hline Fixed Effects & No & Yes & No & Yes \\
\hline Diploma & $\begin{array}{l}-0.010 \\
(0.077)\end{array}$ & $\begin{array}{c}-0.073 \\
(0.069)\end{array}$ & $\begin{array}{c}0.026 \\
(0.084)\end{array}$ & $\begin{array}{l}-0.061 \\
(0.095)\end{array}$ \\
\hline Observations & 431 & 431 & 398 & 398 \\
\hline Community Dummies P-Value & & 0.08 & & 0.074 \\
\hline Hausman Test P-Value & & 0.441 & & 0.774 \\
\hline GED & $\begin{array}{l}-0.080 \\
(0.061)\end{array}$ & $\begin{array}{c}-0.018 \\
(0.052)\end{array}$ & $\begin{array}{c}-0.153^{\star *} \\
(0.073)\end{array}$ & $\begin{array}{l}-0.025 \\
(0.068)\end{array}$ \\
\hline Observations & 432 & 432 & 399 & 399 \\
\hline Community Dummies P-Value & & 0.462 & & 0.431 \\
\hline Hausman Test P-Value & & 0.587 & & 0.871 \\
\hline Education & $\begin{array}{l}-0.473^{*} \\
(0.248)\end{array}$ & $\begin{array}{c}-0.057 \\
(0.261)\end{array}$ & $\begin{array}{l}-0.403 \\
(0.314)\end{array}$ & $\begin{array}{c}0.036 \\
(0.310)\end{array}$ \\
\hline Observations & 432 & 432 & 399 & 399 \\
\hline Community Dummies P-Value & & 0 & & 0 \\
\hline Hausman Test P-Value & & 0.016 & & 0.102 \\
\hline Welfare & $\begin{array}{l}0.142^{*} \\
(0.084)\end{array}$ & $\begin{array}{c}0.064 \\
(0.066)\end{array}$ & $\begin{array}{c}0.126 \\
(0.110)\end{array}$ & $\begin{array}{c}0.062 \\
(0.089)\end{array}$ \\
\hline Observations & 431 & 431 & 398 & 398 \\
\hline Community Dummies P-Value & & 0.064 & & 0.033 \\
\hline Hausman Test P-Value & & 0.848 & & 0.723 \\
\hline Total Income & $\begin{array}{l}-0.003 \\
(2.234)\end{array}$ & $\begin{array}{l}-3.120 \\
(2.976)\end{array}$ & $\begin{array}{c}-0.304 \\
(1.778)\end{array}$ & $\begin{array}{l}-2.688 \\
(2.226)\end{array}$ \\
\hline Observations & 408 & 408 & 378 & 378 \\
\hline Community Dummies P-Value & & 0.762 & & 0.065 \\
\hline Hausman Test P-Value & & 0.277 & & 0.400 \\
\hline Total Wages & $\begin{array}{l}-0.466 \\
(1.952)\end{array}$ & $\begin{array}{l}-1.986 \\
(2.690)\end{array}$ & $\begin{array}{c}-0.705 \\
(1.533)\end{array}$ & $\begin{array}{c}-2.072 \\
(1.961)\end{array}$ \\
\hline Observations & 416 & 416 & 385 & 385 \\
\hline Community Dummies P-Value & & 0.457 & & 0.049 \\
\hline Hausman Test P-Value & & 0.392 & & 0.341 \\
\hline
\end{tabular}

Controls: Age, Conception before 15, smoke, drink, or take drugs during pregnancy.. *** $p<0.01,{ }^{* \star} p<0.05,{ }^{*} p<0.1$. Each cell represents a separate regression 
Table 7A

Effects of Teenage Childbearing on Early Life Outcomes

Out of Wedlock Pregnancies

\begin{tabular}{|c|c|c|c|c|c|c|}
\hline $\begin{array}{l}\text { Specification } \\
\text { Sample } \\
\text { Fixed Effects }\end{array}$ & $\begin{array}{c}\text { OLS } \\
\text { Birth/No } \\
\text { Birth } \\
\text { No } \\
\text { Not Married }\end{array}$ & $\begin{array}{c}\text { OLS } \\
\text { Birth/No } \\
\text { Birth } \\
\text { Yes } \\
\text { Not Married }\end{array}$ & $\begin{array}{c}\text { 2SLS } \\
\text { B/A/M } \\
\text { No } \\
\text { Not Married }\end{array}$ & $\begin{array}{l}\text { 2SLS } \\
\text { B/A/M } \\
\text { Yes } \\
\text { Not } \\
\text { Married }\end{array}$ & $\begin{array}{c}\text { OLS } \\
\text { Birth or } \\
\text { Miscarriage } \\
\text { No } \\
\text { Not Married }\end{array}$ & $\begin{array}{c}\text { OLS } \\
\text { Birth or } \\
\text { Miscarriage } \\
\text { Yes } \\
\text { Not Married }\end{array}$ \\
\hline Diploma & $\begin{array}{c}-0.146^{\star \star \star} \\
(0.044)\end{array}$ & $\begin{array}{c}-0.136^{\star \star \star} \\
(0.035)\end{array}$ & $\begin{array}{c}0.088 \\
(0.078)\end{array}$ & $\begin{array}{l}0.122^{*} \\
(0.072)\end{array}$ & $\begin{array}{l}-0.033 \\
(0.057)\end{array}$ & $\begin{array}{c}-0.049 \\
(0.045)\end{array}$ \\
\hline Observations & 873 & 873 & 873 & 871 & 618 & 618 \\
\hline Community Dummies P-Value & & 0.004 & & 0 & & 0.051 \\
\hline Hausman Test P-Value & & 0.086 & & 0.258 & & 0.206 \\
\hline GED & $\begin{array}{l}-0.017 \\
(0.038)\end{array}$ & $\begin{array}{c}0.015 \\
(0.025)\end{array}$ & $\begin{array}{l}-0.077 \\
(0.071)\end{array}$ & $\begin{array}{l}-0.077 \\
(0.078)\end{array}$ & $\begin{array}{l}-0.042 \\
(0.051)\end{array}$ & $\begin{array}{c}0.001 \\
(0.038)\end{array}$ \\
\hline Observations & 875 & 875 & 875 & 873 & 620 & 620 \\
\hline Community Dummies P-Value & & 0.174 & & 0.052 & & 0.642 \\
\hline Hausman Test P-Value & & 0.458 & & 1 & & 0.604 \\
\hline Education & $\begin{array}{c}-0.889 * \star \star \\
(0.182)\end{array}$ & $\begin{array}{c}-0.779^{\star * \star} \\
(0.124)\end{array}$ & $\begin{array}{c}0.040 \\
(0.332)\end{array}$ & $\begin{array}{c}0.302 \\
(0.343)\end{array}$ & $\begin{array}{l}-0.431^{*} \\
(0.240)\end{array}$ & $\begin{array}{l}-0.032 \\
(0.195)\end{array}$ \\
\hline Observations & 876 & 876 & 876 & 874 & 621 & 621 \\
\hline Community Dummies P-Value & & 0 & & 0 & & 0 \\
\hline Hausman Test P-Value & & 0.002 & & 0.002 & & 0 \\
\hline Welfare & $\begin{array}{c}0.158^{\star \star \star} \\
(0.039)\end{array}$ & $\begin{array}{c}0.088^{\star \star \star} \\
(0.027)\end{array}$ & $\begin{array}{l}0.136^{*} \\
(0.071)\end{array}$ & $\begin{array}{c}0.041 \\
(0.058)\end{array}$ & $\begin{array}{c}0.153^{\star \star *} \\
(0.057)\end{array}$ & $\begin{array}{c}0.032 \\
(0.041)\end{array}$ \\
\hline Observations & 876 & 876 & 876 & 874 & 621 & 621 \\
\hline Community Dummies P-Value & & 0 & & 0 & & 0.009 \\
\hline Hausman Test P-Value & & 0.039 & & 0.021 & & 0.001 \\
\hline Total Income & $\begin{array}{c}-2.278^{* *} \\
(1.056)\end{array}$ & $\begin{array}{l}-2.378^{*} \\
(1.237)\end{array}$ & $\begin{array}{l}-0.984 \\
(2.577)\end{array}$ & $\begin{array}{l}-0.792 \\
(2.435)\end{array}$ & $\begin{array}{l}-1.491 \\
(1.642)\end{array}$ & $\begin{array}{l}-2.282 \\
(1.890)\end{array}$ \\
\hline Observations & 830 & 830 & 830 & 827 & 583 & 583 \\
\hline Community Dummies P-Value & & 0.215 & & 0.07 & & 0.038 \\
\hline Hausman Test P-Value & & 0.640 & & 0.821 & & 0.455 \\
\hline Total Wages & $\begin{array}{c}-3.224^{\star \star \star} \\
(1.104)\end{array}$ & $\begin{array}{l}-2.124^{*} \\
(1.139)\end{array}$ & $\begin{array}{l}-1.282 \\
(2.461)\end{array}$ & $\begin{array}{c}0.162 \\
(2.177)\end{array}$ & $\begin{array}{l}-2.077 \\
(1.596)\end{array}$ & $\begin{array}{l}-1.740 \\
(1.780)\end{array}$ \\
\hline Observations & 848 & 848 & 848 & 845 & 601 & 601 \\
\hline Community Dummies P-Value & & 0.054 & & 0.009 & & 0.025 \\
\hline Hausman Test P-Value & & 0.270 & & 0.209 & & 0.307 \\
\hline
\end{tabular}

Controls: Age, Conception before 15, smoke, drink, or take drugs during pregnancy. ${ }^{* \star} p<0.01,{ }^{* \star} p<0.05,{ }^{*} p<0.1$ Notes: No Birth includes abortions and miscarriages, $B / A / M$ includes births, abortions, and miscarriages. Each cell represents a separate regression 
Table 8A

Robustness Results using Limited Controls

\begin{tabular}{|c|c|c|c|c|c|c|}
\hline $\begin{array}{l}\text { Specification } \\
\text { Sample } \\
\text { Fixed Effects }\end{array}$ & $\begin{array}{l}\text { OLS } \\
\text { Birth/No } \\
\text { Birth } \\
\text { No }\end{array}$ & $\begin{array}{l}\text { OLS } \\
\text { Birth/No } \\
\text { Birth } \\
\text { Yes }\end{array}$ & $\begin{array}{l}2 \mathrm{SLS} \\
\text { B/A/M } \\
\text { No }\end{array}$ & $\begin{array}{l}2 \mathrm{SLS} \\
\text { B/A/M } \\
\text { Yes }\end{array}$ & $\begin{array}{c}\text { OLS } \\
\text { Birth or } \\
\text { Miscarriage } \\
\text { No }\end{array}$ & $\begin{array}{c}\text { OLS } \\
\text { Birth or } \\
\text { Miscarriage } \\
\text { Yes }\end{array}$ \\
\hline $\begin{array}{l}\text { Observations } \\
\text { Community Dummies P-Value } \\
\text { Hausman Test P-Value }\end{array}$ & $\begin{array}{c}-0.157^{\star \star \star} \\
(0.041) \\
987\end{array}$ & $\begin{array}{c}-0.139 * \star \star \\
(0.034) \\
987 \\
0.029 \\
0.056\end{array}$ & $\begin{array}{c}0.014 \\
(0.071) \\
987\end{array}$ & $\begin{array}{c}0.051 \\
(0.074) \\
985 \\
0.003 \\
0.077\end{array}$ & $\begin{array}{c}-0.061 \\
(0.052) \\
727\end{array}$ & $\begin{array}{c}-0.070 \\
(0.043) \\
727 \\
0.133 \\
0.244\end{array}$ \\
\hline $\begin{array}{l}\text { GED } \\
\text { Observations } \\
\text { Community Dummies P-Value } \\
\text { Hausman Test P-Value }\end{array}$ & $\begin{array}{c}-0.017 \\
(0.038) \\
989\end{array}$ & $\begin{array}{c}0.012 \\
(0.026) \\
989 \\
0.023 \\
0.464\end{array}$ & $\begin{array}{c}-0.066 \\
(0.067) \\
989\end{array}$ & $\begin{array}{c}-0.084 \\
(0.070) \\
987 \\
0.004 \\
0.375\end{array}$ & $\begin{array}{c}-0.046 \\
(0.049) \\
729\end{array}$ & $\begin{array}{c}-0.012 \\
(0.033) \\
729 \\
0.195 \\
0.164\end{array}$ \\
\hline $\begin{array}{l}\text { Education } \\
\text { Observations } \\
\text { Community Dummies P-Value } \\
\text { Hausman Test P-Value }\end{array}$ & $\begin{array}{c}-0.886^{\star \star \star} \\
(0.151) \\
990\end{array}$ & $\begin{array}{c}-0.766^{\star \star \star} \\
(0.117) \\
990 \\
0 \\
0.007\end{array}$ & $\begin{array}{c}-0.025 \\
(0.287) \\
990\end{array}$ & $\begin{array}{c}0.199 \\
(0.294) \\
988 \\
0 \\
0\end{array}$ & $\begin{array}{c}-0.386 \star \\
(0.208) \\
730\end{array}$ & $\begin{array}{c}-0.047 \\
(0.158) \\
730 \\
0 \\
0.005\end{array}$ \\
\hline $\begin{array}{l}\text { Welfare } \\
\text { Observations } \\
\text { Community Dummies P-Value } \\
\text { Hausman Test P-Value }\end{array}$ & $\begin{array}{c}0.126 * \star \star \\
(0.035) \\
989\end{array}$ & $\begin{array}{c}0.084 * \star \star \\
(0.026) \\
989 \\
0.001 \\
0.146\end{array}$ & $\begin{array}{c}0.080 \\
(0.069) \\
989\end{array}$ & $\begin{array}{c}-0.006 \\
(0.063) \\
987 \\
0 \\
0.002\end{array}$ & $\begin{array}{c}0.101^{\star} \\
(0.052) \\
729\end{array}$ & $\begin{array}{c}0.027 \\
(0.041) \\
729 \\
0.001 \\
0.029\end{array}$ \\
\hline $\begin{array}{l}\text { Total Income } \\
\text { Observations } \\
\text { Community Dummies P-Value } \\
\text { Hausman Test P-Value }\end{array}$ & $\begin{array}{c}-2.235^{\star \star} \\
(0.933) \\
935\end{array}$ & $\begin{array}{c}-2.448^{\star *} \\
(1.168) \\
935 \\
0.367 \\
0.537\end{array}$ & $\begin{array}{c}-1.480 \\
(2.318) \\
935\end{array}$ & $\begin{array}{c}-1.115 \\
(2.313) \\
933 \\
0.192 \\
0.017\end{array}$ & $\begin{array}{c}-1.690 \\
(1.535) \\
685\end{array}$ & $\begin{array}{c}-2.419 \\
(1.805) \\
685 \\
0.086 \\
0.425\end{array}$ \\
\hline $\begin{array}{l}\text { Total Wages } \\
\text { Observations } \\
\text { Community Dummies P-Value } \\
\text { Hausman Test P-Value }\end{array}$ & $\begin{array}{c}-3.251^{\star * *} \\
(0.941) \\
954\end{array}$ & $\begin{array}{c}-2.239 * * \\
(1.091) \\
954 \\
0.085 \\
0.177\end{array}$ & $\begin{array}{c}-1.827 \\
(2.228) \\
954\end{array}$ & $\begin{array}{c}-0.910 \\
(2.036) \\
952 \\
0.026 \\
0.311\end{array}$ & $\begin{array}{c}-2.336 \\
(1.492) \\
703\end{array}$ & $\begin{array}{c}-2.178 \\
(1.704) \\
703 \\
0.019 \\
0.489\end{array}$ \\
\hline
\end{tabular}

Controls: Age, Conception before 15. ${ }^{\star \star \star} p<0.01,{ }^{\star \star} p<0.05,{ }^{*} p<0.1$ Notes: No Birth includes abortions and miscarriages, $B / A / M$ includes births, abortions, and miscarriages. Each cell represents a separate regression 
Table 9A

Community Level Variables Predicting Outcomes

\begin{tabular}{|c|c|c|c|c|c|c|}
\hline Outcome & $\begin{array}{l}\text { High School } \\
\text { Diploma }\end{array}$ & GED & $\begin{array}{l}\text { Yrs of } \\
\text { Education }\end{array}$ & $\begin{array}{l}\text { Welfare } \\
\text { Receipt }\end{array}$ & $\begin{array}{l}\text { Total } \\
\text { Income }\end{array}$ & $\begin{array}{l}\text { Labor } \\
\text { Income }\end{array}$ \\
\hline \multirow[t]{2}{*}{ Median Income } & -0.009 & 0.001 & -0.001 & $-0.016^{*}$ & $0.464^{*}$ & $0.469^{\star \star}$ \\
\hline & $(0.007)$ & $(0.005)$ & $(0.035)$ & $(0.008)$ & $(0.236)$ & $(0.212)$ \\
\hline \multirow[t]{2}{*}{$\%$ in Poverty } & -0.020 ** & -0.008 & -0.011 & -0.012 & 0.134 & 0.192 \\
\hline & $(0.008)$ & $(0.006)$ & $(0.036)$ & $(0.009)$ & $(0.185)$ & $(0.182)$ \\
\hline \multirow[t]{2}{*}{$\%$ Black } & 0.232 & -0.046 & 0.063 & -0.087 & -1.802 & 4.949 \\
\hline & $(0.235)$ & $(0.194)$ & (1.161) & $(0.263)$ & (7.099) & $(6.312)$ \\
\hline \multirow[t]{2}{*}{ Rural } & $0.089^{*}$ & $-0.073^{*}$ & 0.195 & -0.064 & 0.884 & 0.806 \\
\hline & $(0.052)$ & $(0.042)$ & $(0.205)$ & $(0.065)$ & $(1.774)$ & $(1.566)$ \\
\hline \multirow[t]{2}{*}{ Urban } & $-0.121^{\star \star}$ & -0.058 & $-0.427^{* *}$ & 0.023 & 1.202 & 1.410 \\
\hline & $(0.050)$ & $(0.060)$ & $(0.200)$ & $(0.056)$ & $(1.147)$ & $(0.995)$ \\
\hline \multirow[t]{2}{*}{ Violent Crime } & 0.130 & -0.085 & 0.226 & 0.034 & 0.885 & -2.979 \\
\hline & $(0.105)$ & $(0.067)$ & $(0.431)$ & $(0.100)$ & $(2.437)$ & $(2.138)$ \\
\hline \multirow[t]{2}{*}{ Total Crime } & $-0.037^{* \star}$ & 0.014 & -0.077 & 0.003 & -0.004 & 0.373 \\
\hline & $(0.018)$ & $(0.013)$ & $(0.081)$ & $(0.020)$ & $(0.429)$ & $(0.382)$ \\
\hline \multirow[t]{2}{*}{ AFDC Benefits } & 0.000 & -0.000 & 0.003 & $0.002^{* * *}$ & -0.015 & -0.011 \\
\hline & $(0.001)$ & $(0.001)$ & $(0.004)$ & $(0.001)$ & $(0.016)$ & $(0.014)$ \\
\hline \multirow[t]{2}{*}{ Unemployment Rate } & 1.406 & $3.638^{\star \star \star}$ & -3.157 & 1.455 & -36.185 & $-70.519^{*}$ \\
\hline & $(2.568)$ & $(1.372)$ & $(8.622)$ & $(1.833)$ & $(39.305)$ & (38.242) \\
\hline \multirow[t]{2}{*}{$\%$ Welfare } & -0.317 & -0.035 & $-2.096^{*}$ & 0.065 & 3.002 & 2.725 \\
\hline & $(0.226)$ & $(0.220)$ & $(1.234)$ & $(0.426)$ & $(7.170)$ & $(7.835)$ \\
\hline \multirow[t]{2}{*}{$\%$ College Graduates } & 0.610 & -0.153 & 1.411 & -0.020 & -7.778 & -13.793 \\
\hline & $(0.478)$ & $(0.267)$ & $(2.505)$ & $(0.510)$ & $(12.559)$ & $(12.377)$ \\
\hline \multirow[t]{2}{*}{ Sex Ratio (17-21) } & 0.078 & $0.314^{\star *}$ & -0.253 & 0.260 & -5.916 & $-7.439 * *$ \\
\hline & $(0.162)$ & $(0.122)$ & $(0.849)$ & $(0.169)$ & $(3.948)$ & $(3.334)$ \\
\hline \multirow[t]{2}{*}{ Constant } & 0.255 & $-0.531^{*}$ & $8.429^{\star \star \star}$ & 0.627 & $-23.382^{* *}$ & $-22.909^{\star *}$ \\
\hline & $(0.439)$ & $(0.286)$ & $(1.679)$ & $(0.434)$ & $(10.741)$ & $(9.818)$ \\
\hline Observations & 687 & 689 & 690 & 689 & 648 & 664 \\
\hline R-squared & 0.14 & 0.07 & 0.16 & 0.08 & 0.11 & 0.13 \\
\hline Fpvalue & 0.000 & 0.001 & 0.000 & 0.142 & 0.007 & 0.012 \\
\hline
\end{tabular}

Additional Controls: Age, Conception before 15, smoke, drink, or take drugs during pregnancy.

${ }^{* \star *} p<0.01,{ }^{* \star} p<0.05,{ }^{*} p<0.1$ 


\section{$\underline{\text { References }}$}

Abel, E. L. (1997). Maternal alcohol consumption and spontaneous abortion. Alcohol and Alcoholism, 3, 211-219.

An, C.-B., Haveman, R., \& Wolfe, B. (1993). Teen out-of-wedlock births and welfare receipt: The role of childhood events and economic circumstances. Review of Economics and Statistics, 75, 195-208.

Ashcraft, A., \& Lang, K. (2006). The consequences of teenage childbearing (NBER Working Paper No. 12485).

Brent, R. L., \& Beckmann, D. A. (1994). The contribution of environmental teratogens to embryonic and fetal loss. Clinical Obstetrics and Gynecology, 37, 646-70.

Chasnoff, I. J., Burns, W. J., Schnoll, S. H., \& Burns, K. A. (1985). Cocaine use in pregnancy. New England Journal of Medicine, 313, 666-669.

Coleman, P. K. (2006). Resolution of unwanted pregnancy during adolescence through abortion versus childbirth: Individual and family predictors and psychological consequences.” Journal of Youth and Adolescence, 35, 903-911.

Garcia-Enguidanos, A., Calle, M. E., Valero, J., Luna, S., \& Dominguez-Rojas, V. (2002). Risk factors in miscarriage: A review. European Journal of Obstetrics and Gynecology and Reproduction Biology, 102, 111-119.

Geronimus, A. T., \& Korenman, S. (1992). The socioeconomic consequences of teen childbearing reconsidered. The Quarterly Journal of Economics, 107, 1187-1214.

Haveman, R., Wolfe, B., \& Peterson, E. (1997). Outcomes for teens and young adults of adolescent parents. In R. Maynard (Ed.), Kids Having Kids: Economic Costs and Social Consequences of Teen Pregnancy. Washington, D.C.: Urban Institute Press.

Haveman, R., Wolfe, B., \& Wilson, K. (2001). The role of economic incentives in teenage nonmarital childbearing choices. Journal of Public Economics, 81, 473-511.

Hoffman, S. D. (2003). The socio-economic effects of teen childbearing re-considered: A re-analysis of the teen miscarriage experiment (Working Paper No. 03-08). Newark, Delaware: University of Delaware, Department of Economics.

Hope, T., Wilder, E., \& Terling Watt, T. (2003). The relationships among adolescent pregnancy, pregnancy resolution, and juvenile delinquency. The Sociological Quarterly, 44, 555-576. 
Hotz, V. J., Williams McElroy, S., \& Sanders, S. G. (2005). Teenage childbearing and its life cycle consequences: Exploiting a natural experiment. Journal of Human Resources, 40, 683-715.

Klepinger, D., Lundberg, S., \& Plotnick, R. (1999). How does adolescent fertility affect the human capital and wages of young women? Journal of Human Resources,34, 421448.

Lee, D. (2007). A counterfactual analysis of the early socioeconomic effects of teenage childbearing in the presence of selection bias (Mimeo). Chapel Hill, N.C.: University of North Carolina at Chapel Hill, Carolina Population Center.

Moore, K.A., \& Waite L.C. (1977). Early childbearing and educational attainment. Family Planning Perspectives 9: 220-225.

Ribar, D. C. (1994). Teenage fertility and high school completion. Review of Economics and Statistics, 76, 413-424.

Ribar, D. C., (1999). The socioeconomic consequences of young women's childbearing: Reconciling disparate evidence. Journal of Population Economics, 12, 547-565.

Rosenzweig, M. R., \& Wolpin, K.I. (1995). Sisters, siblings, and mothers: The effect of teen-age childbearing on birth outcomes in a dynamic family context. Econometrica, 63, 303-326.

Wolfe B., Haveman, R., Pence, K., \& Schwabish, J. (2007). Do youth nonmarital childbearing choices reflect income and relationship expectations? Journal of Population Economics, 20, 73-100. 